Historic, Archive Document

Do not assume content reflects current scientific knowledge, policies, or practices. 



\section{Lisco}

GUARANTEED SEEDS

$6 9 4 \longdiv { 7 2 7 9 }$

$$
\begin{aligned}
& \text { ALFALFAS } \\
& \text { SEED CORN } \\
& \text { FIELD SEEDS }
\end{aligned}
$$
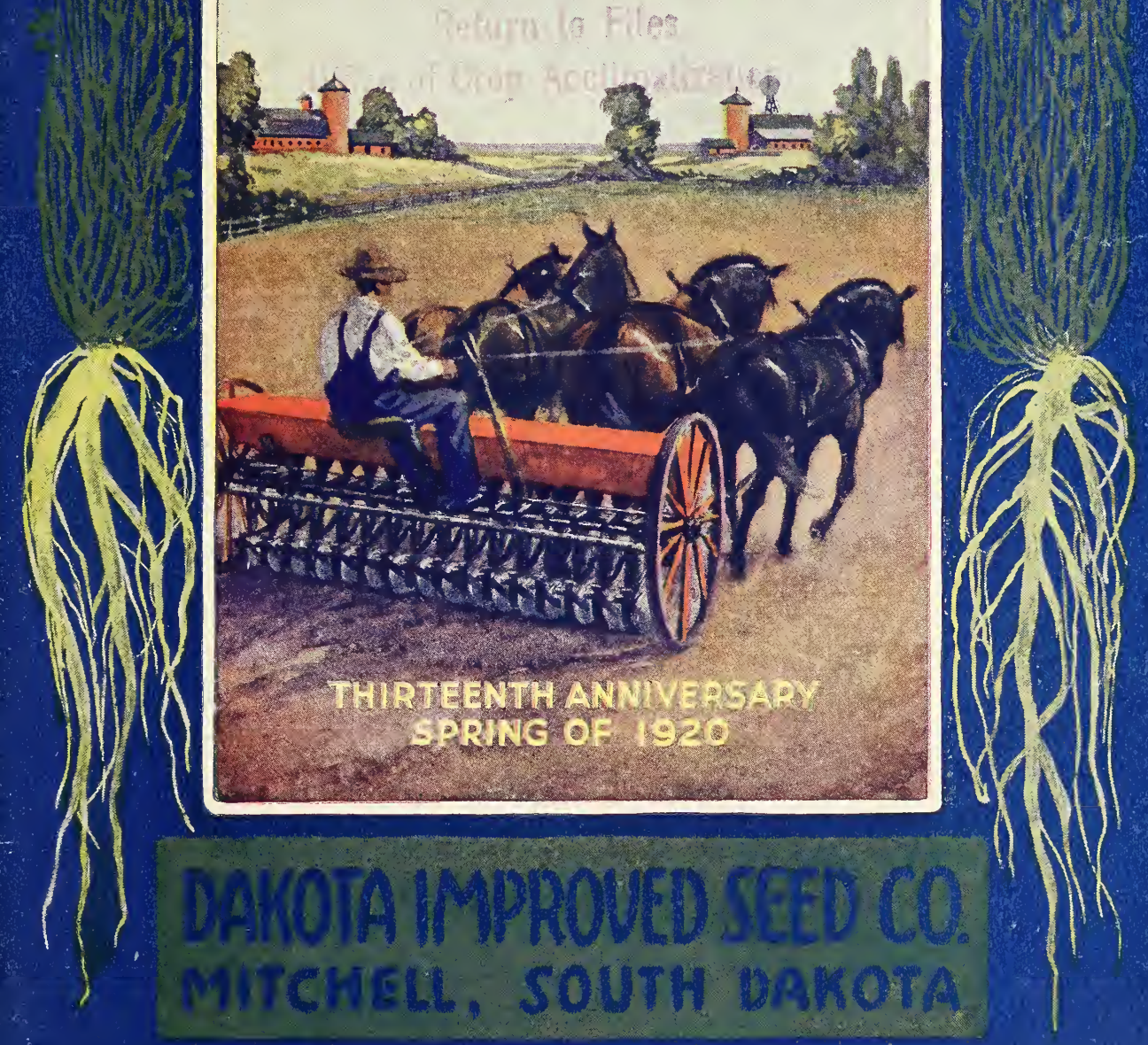


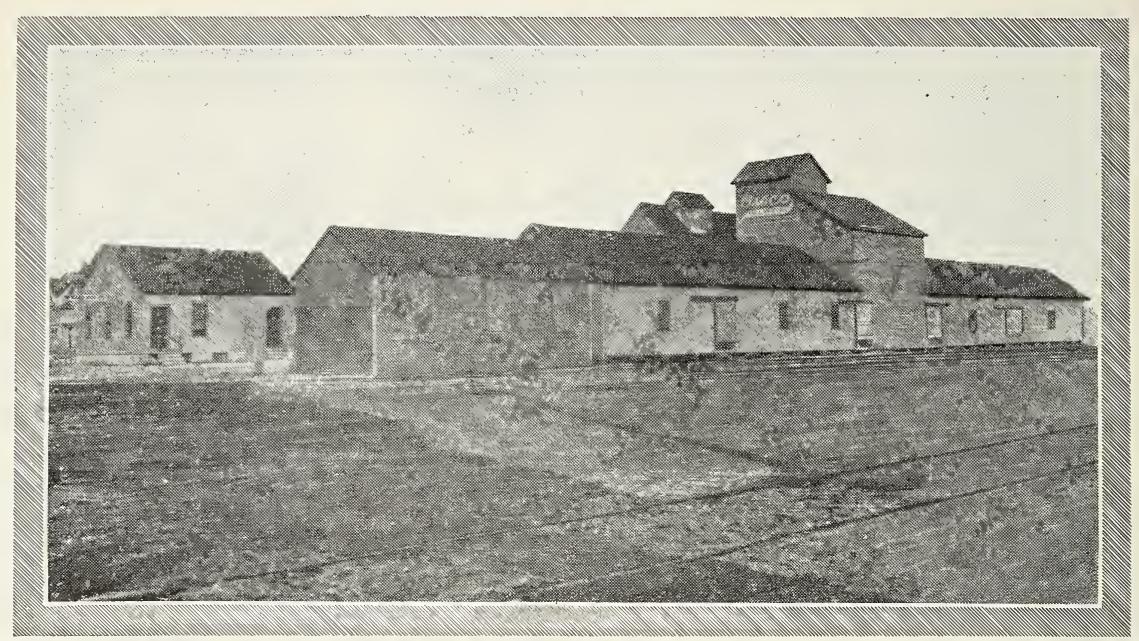

\section{The Home of Liscos}

Since the establishment of the Dakota Improved Seed Co., the home of Disco Guaranteed Seeds has grown so that almost every year added improvements as well as increased space and facilities have been necessary to take care of the rapidly growing business. Even with the tremendous increase in labor and material costs, we were again forced to increase our capacity.

Neither time nor money has been spared in bringing this equipment up to the most modern standard, so as to enable us to handle all kinds of field seeds with accuracy and dispatch for our constantly growing list of customers. Again, this enables us to insure better quality in our seeds and we overlook no opportunity to take advantage of the most modern equipment to insure a standard of quality in seeds that is bound to make the DISCO trade mark the BUY word in all that is good in seeds.

This Company was organized for the purpose of growing and distributing reliable field seeds. These seeds are grown for us in South Dakota by reliable growers under our supervisicn. That its work is well founded is proven in the steady increase in volume of business.

"DISCO GUARANTEED SEEDS" are recognized by all leading agricultural experts in the United States as being superior Northern Grown Field Seeds. We possess a particular advantage in this respect because of our location and because we hold rigidly to our policy and specialize in Hardy Pedigreed and Registered Alfalfas, Sweet Clover, Grasses and Improved Early Varieties of Seed Corn.

Read this book carefully. It tells the plain truth about "DISCO GUARANTEED SEEDS" and will interest you.

\section{DAKOTA IMPROVED SEED CO.} By W. S. HILL, President and Treasurer

January, 1920 . 

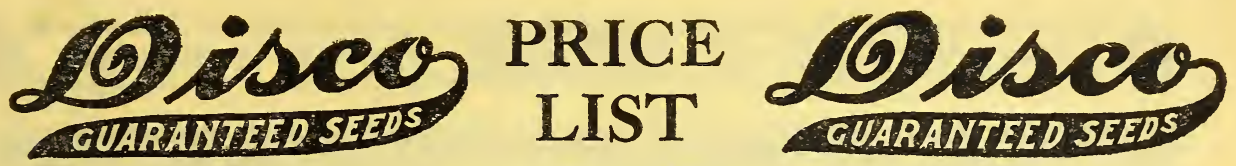

January 1, 1920.

United States Food Administration License Number G-41870.

The prices given herewith are those in effect January 1, 1920, and as near as we can anticipate them for the season. All prices are subject to market changes. We invite correspondence on seeds where prices are likely to vary, or on any seed where large quantities are desired.

All prices quoted are f. o. b. Mitchell, S. D. Freight or express to be paid by customer. If delivered prices are required, write us and we will quote delivered prices. In ordering by parcei post, your postmaster will tell you in what zone from Mitchell you are located, so that your remittance will include the postage.

PRICES SUBJECT TO MARKET CHANGES. BAGS WEIGHED IN FREE.

DISCO REGISTERED ALFALFAS

Per lb. Per $100 \mathrm{lb.}$ Per bu.

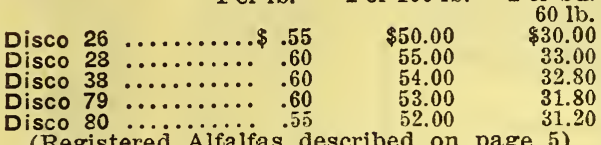

(Registered Alfalfas described on page 5)

DISCO PEDIGREED ALFALFAS

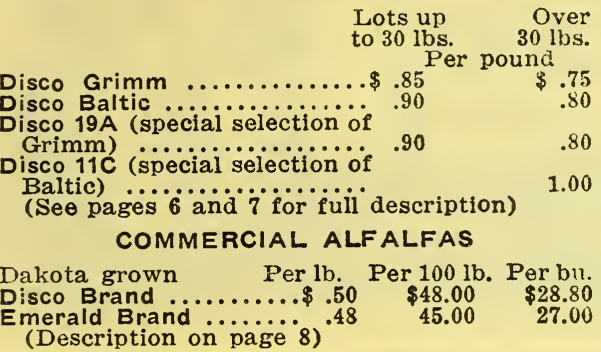

\section{SWEET CLOVERS}

Per lb.

White Blossom, hulled Disco Brand.....\$ .35 White Blossom, hulled Emerald Brand.... .30

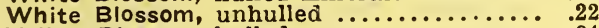

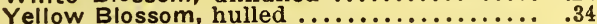
All hulled seeds scarified.

(See pages 10 and 11 for full description)

\section{DISCO CLOVERS}

Per lb. Per $100 \mathrm{lb}$.

Disco Brand Medium Red ......\$.60 $\$ 58.00$

Emerald Brand Medium Red.... .60

Disco Brand Mammoth Red .... .65 60.00

Alsike ........................60 $\quad .60 \quad 58.00$

White or Dutch ciover........... .85 75.00

DISCO TIMOTHY AND GRASS SEEDS

Per $100 \mathrm{lb}$. Per bu.

Timothy ................ \$15.00 \$6.75

Timothy, Alsike mixed ( $1 / 3 \mathrm{Al}$ -

sike, $2 / 3$ Timothy) ..........26.00

Timothy, Red Clover mixed ( $1 / 3$

Clover, 2/3 Timothy) .........29.00

Timothy, Alsike mixed $(1-i)$

13.05

Alsike, $9-10$ Timothy) Per bushel ......\$8.00

Per $1 \mathrm{~b}$.

Permanent Pasture Mixture ........... $\$ .27$

Permanent Meadow Mixture ..............27

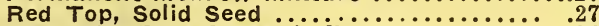

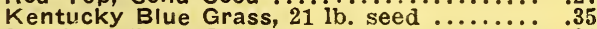

Slender Wheat Grass .................. 28

English Blue Grass or Meadow Fescue ... .40

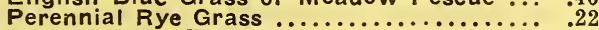

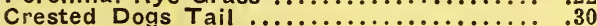

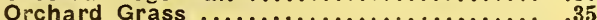

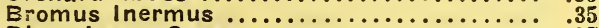

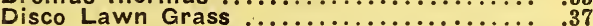

(Described on pages 23 and 26 )

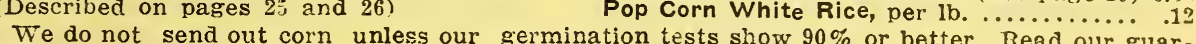
antee on corn found on inside of back cover.

Per lb.

Dakota Amber Sorghum Cane ..........15 Fodder Canes

Dakota Early Fodder Cane ..............................

Southern Grown Fodder Cane ....................

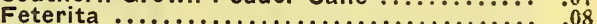

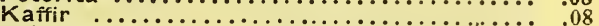

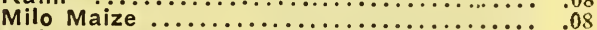

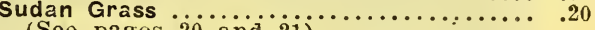

(See pages 20 and $2 i$ )
DISCO MILLETS

Per $100 \mathrm{lb}$

Common, 50 lb. per bu. .............\$6.00

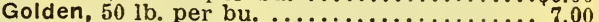

Dakota Kursk, $50 \mathrm{lb}$. per bu. ............. 7.00

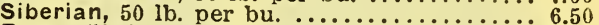

Proso, 50 lb. per bu.

Hog or Broom Corn, $50 \mathrm{ib}$ per bu. ....... 5.00

Early Fortune, 50 lb. per bu. ............6. 6.00

Japanese or Billion Dollar Grass, $36 \mathrm{ib}$.

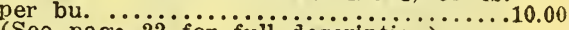

(See page 22 for full description) PEAS AND BEANS

Canada Field Peas ................ Per bu.

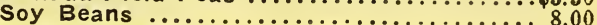

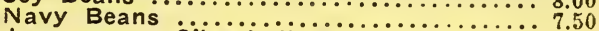

Japanese or silverhuli Buckwheat (Page

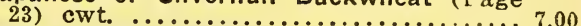

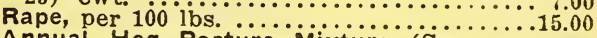

Annual Hog Pasture Mixture (See page

30) per $100 \mathrm{lbs} . \ldots \ldots \ldots \ldots \ldots \ldots \ldots \ldots . . . \ldots \ldots{ }_{10}$

Mammoth Long Red Mangei, per $\mathrm{ib} . \ldots . . .10 .00$ MISCELLANEOUS

Swedish Select Oats ................ $\$ 1.35$

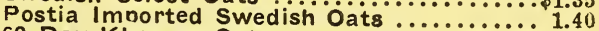

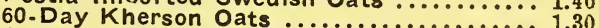

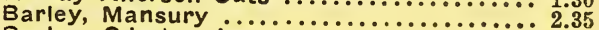

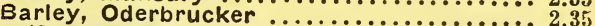

(See page 27)

Marquis Wheat .................... 4.00

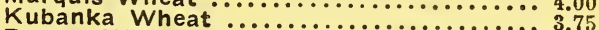

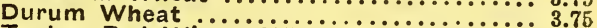

Turkey Red Winter Wheat .........

Speltz, 42 lbs. ..................... 1.90 (See page 28)

Spring Rye ...

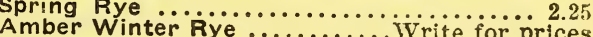

Flax Seed ...............Write for prices (See page 29)

\section{Shelled ana Graded}

\section{SEED CORN} Disco 90.Day White Dent (See page 12) $\$ 5.00$ Minnesota 13 Yellow Dent (See page 14)... Disco Early Murdock Yellow Dent (pg. 15) 5.00 Wimples Yellow Dent (See page 15) ..... 5.00 Disco Pride, Yellow Dent (See page 16 )... 5.00 Northwestern Dent (See page 17) ....... 5. 5.00 Disco White Flint (See page 18) ...........6.00 Disco Gehu Flint (See page 18) .............6. 6.00

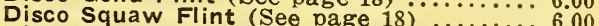
Disco Early Fodder (See page 19) …..... Disco Medium Fodder (See page 19) ….... Sweet Fodder Corn bu. 46 lb. (See page 19 ) 6.50 



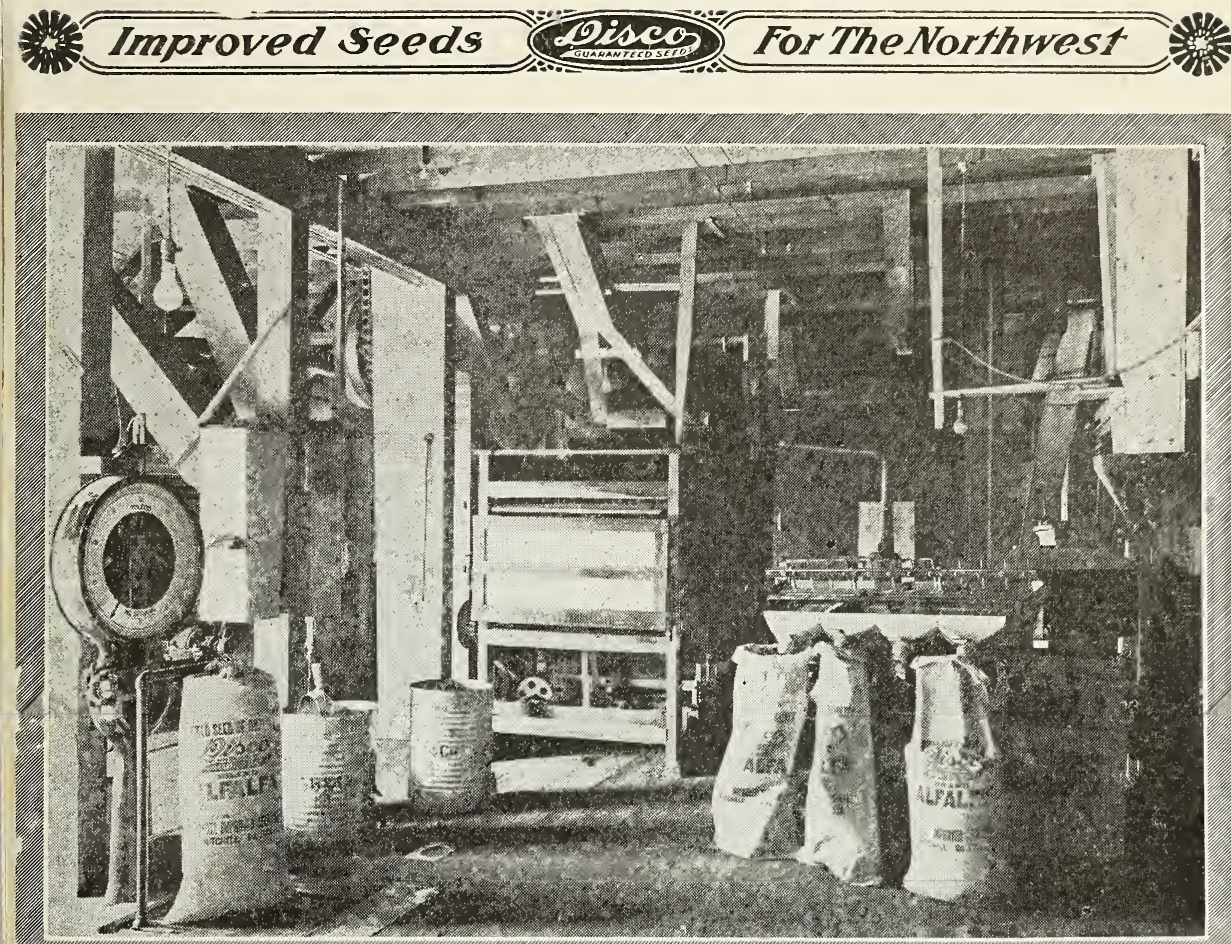

A glimpse of our cleaning facilities.

\section{DISCO CLEANING FACILITIES ARE THE BEST.}

This battery of cleaning machinery contains the Mammoth Clipper Cleaner (at the left of the picture) through which all DISCO Guaranteed Seeds must pass to insure DISCO quality. This is the most modern type of suction, screen and blast cleaner. After the seed has been cleaned by this mill once (or twice, if necessary), it passes over the little gravity mill (at the right of the picture) where the seed is separated by gravity. This gravity separator is the last word in efficient cleaning machinery. The seed is separated according to weight, - thus eliminating all small, light or dead seed and turning out only the big, plump, bold berry, which makes DISCO Quality.

Through the efficiency of this cleaning system and our improved methods of handling and working the various kinds of seed through our warehouse, we have been able to set a standard of quality that is very hard to beat.

\section{SEEDMEN'S RESPONSIBILITY.}

There is no line of commercial activity in which the buyer is so dependent upon the judgment and responsibility of the seller as in the seed business. The quality of seeds cannot be judged by their appearance, for generally speaking, good and poor seed all look alike. The buyer may be able to pass judgment on color, plumpness and freedom of weed seeds and foreign matter, but he cannot judge vitality, trueness to type of productiveness. For these all-important essentials the buyer must depend upon the merchant. The grade and variety in most cases is consistent with the price he pays. The great majority of the public, however, are fast becoming educated to the advantage of using high quality seed as they realize that big crops cannot be produced by seed of inferior quality.

Therefore, buy DISCO Guaranteed Seeds and get the best. 


\section{Three Famous Disco Alfalfas}
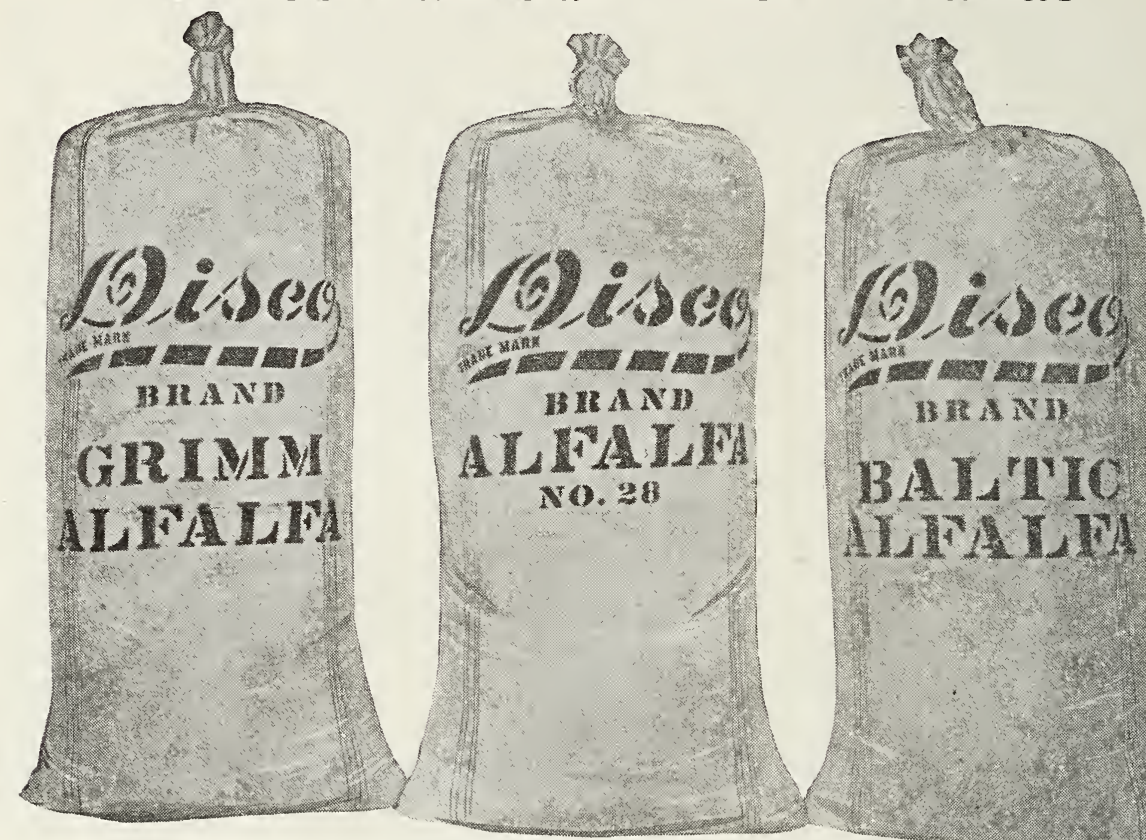

\section{Alfalfa and Lucerne}

There is a wonderful history to the "Wonder Crop of the World" Alfalfa. Only a few people are yet acquainted with alfalfa or the history of the plant. If every farmer in the United States knew the possibilities that lie in the production of this Wonder Crop, seed enough could not be produced to supply the demand for years to come.

Stop! Think a moment! Do you realize alfalfa history dates back as far as 490 B. C. where we find its original home in Asia. The word "alfalfa" is of Arabic origin, meaning "The Best Fodder." The old patriarchs of those days "stopped to think" and realized the exceptional value of this Wonder Crop. And with their crude methods saved the seed, tilled the soil, increased their acreage and provided food for their flocks.

\footnotetext{
Oakland, Maine,

March 28, 1919 .

Dakota Improved Seed Co.,

Mitehell, S. D.

I have in some way mislaid your catalogue and so have not your exact prices. I am enclosing check for $\$ 25.00$. Please send me that value of a good commercial grade of Alfalfa seed. I have been experimenting with Alfalfa for some time and while it is very hard to get a stand, I have never had any plants, grown from your seed, winter-
}

Their dissatisfied brothers migrated from one country to another very much as the people of the world do today. Some of the more progressive ones carried with them alfalfa seed, and so it found its way to all parts of the world. It has made wonderful progress in America. Alfalfa can be grown in every State in the Union. It is no longer an experiment and the happy American farmer, who is growing it, rightfully calls it the "Wonder Crop of the World."

Talking about alfalfa-thinking about alfalfa-and dreaming about what alfalfa might do for your farm and flocks will not get alfalfa for you. Resolve to give Alfalfa a chance this very year. Get the Hardy Dakota grown DISCO Registered or Pedigreed Alfalfa seed and your success is assured.

kill. I intend to persevere until I make Alfalfa a standard crop around here. I have one patch five years old and it is stronger every year.

Ship to Norridgewock by American Express. I should have had this check certified but we are eight miles from the bank so am taking a chance. If you doubt this check send goods by express, C. O. D.

\section{Yours,}

(Signed) T. A. Woodsum.

For Prices See Special Sheet Inside of Front Cover. 


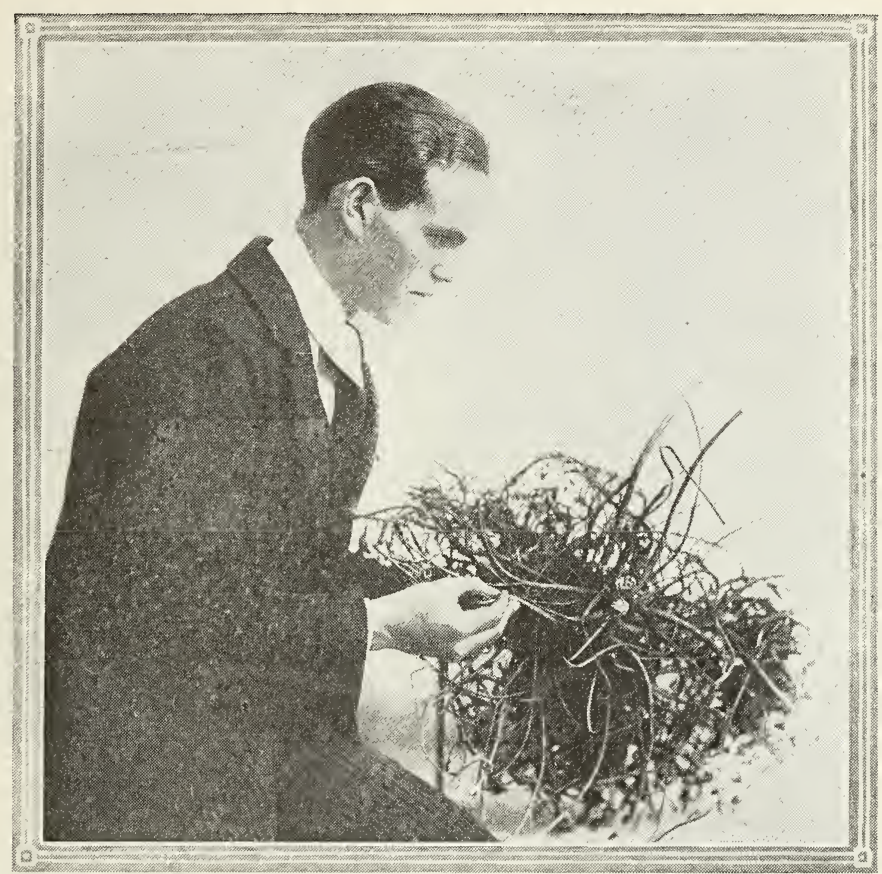

This illustration shows the branched root system and the wide spreading crown that is characteristic of the Drsco Pedigreed varieties of alfalfa.

\section{Looking Ahead For Several Years}

That is really what you are doing when you buy DISCO Hardy Dakota-Grown alfalfa seed. Looking ahead not only to the lasting qualities of the seed or plant, but to its productiveness.

Since the establishment of DISCO over 13 years ago we have spared no effort, time or money in our alfalfa nursery plot. That these efforts have been well rewarded is proven by the fact that we have been able to select a few very hardy and productive varieties of alfalfa from the large number tested and by the aid of the Agricultural Colleges throughout the United States have been able to select four DISCO pedigreed varieties and five DISCO registered varieties that stand in a class by themselves. They answer every possible requirement (according to the order enumerated) in any section of the United States.

To illustrate: On the 5 th of December, 1919, we received a very pleasing report on our DISCO Baltic alfalfa from Essex County, N. Y., where in eight tests for productiveness and hardiness, in the heart of the Adirondack Mountains, Baltic took four firsts, three seconds and one third, against nine different lots of seed. DISCO Grimm was not given a trial but DISCO 19-A took the three first where DISCO Baltic took second. We wish we had room to give you full details of these tests. This was an unsolicited report and ought to convince you that DISCO Hardy Dakota-grown alfalfa seed is the kind you must have to get the best results. 


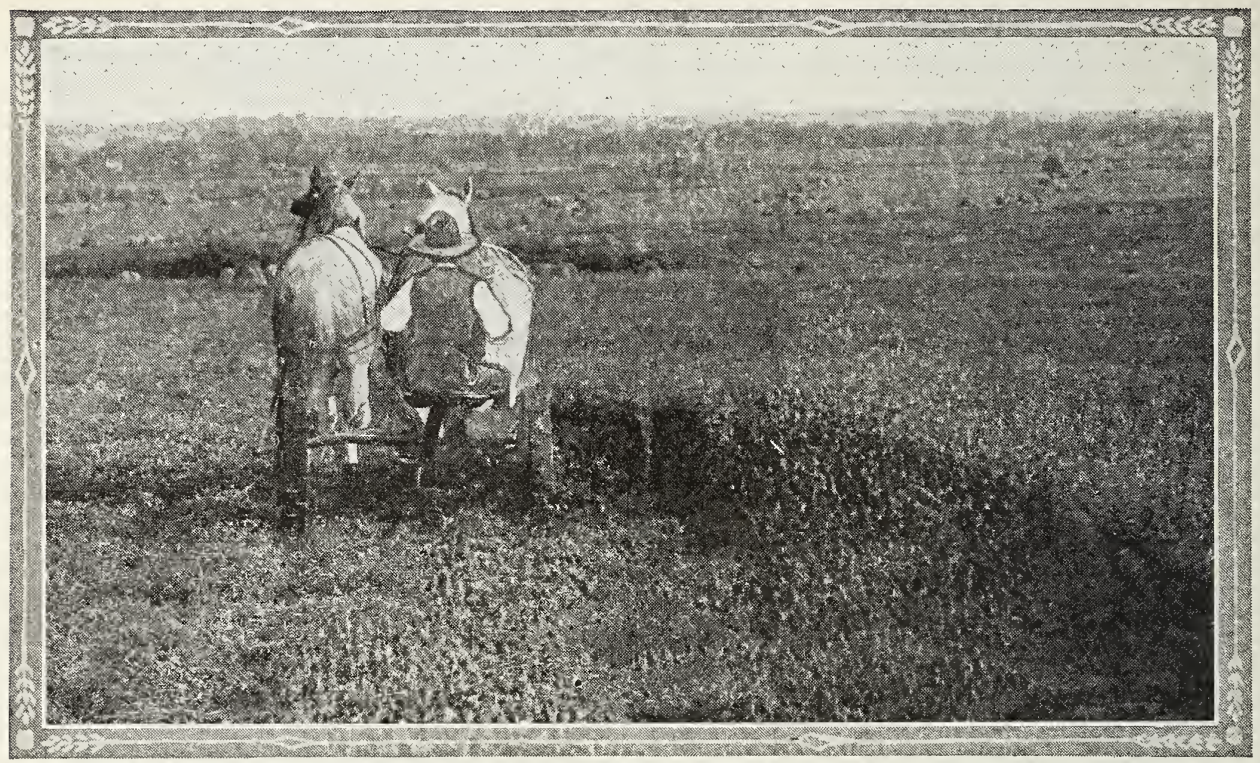

\section{Hardy Alfalfas}

There is a vast difference between hardy alfalfa and just alfalfa.

There are naturally two distinctive kinds of alfalfa. One which is termed common alfalfa, having one long tap root and the plant producing nearly a true purple and blue flower. There are hardy and non-hardy strains of the common alfalfa. For instance, seed coming from the South, in Kansas and Missouri will not stand the severe winters of the North. The southern seed may make a wonderful growth the first season, but on account of its being a non-hardy southern grown plant, it naturally winter-kills. The hardy Dakota grown seed is acclimated to the rigid winters of the North. It is grown in a territory with a wide range of temperatures and a small amount of moisture and must be hardy to survive. From this variety comes the Registered DISCO Alfalfa.

The second distinctive variety of alfalfa is commercially known as the Variegated alfalfa. This variety has a variegated blossom and a branch or spreading root system. The crown of the plant is naturally larger and grows more underground.
There are many different strains of this variety. The hardiest of all and without a doubt the best and most favorably known strains are the Grimm and Baltic alfalfa. These are known the world over as being the hardiest alfalfas in every respect. They have an immense spread of crown, with the underground buds, protected by the soil and grow in such a way as to withstand the severe winter weather without a snow covering. The wonderful branched or spreading root system enables it to stand the heaving of the ground from frost in the spring-enables the plant to draw more moisture in dry seasons-makes a more desirable plant to grow on land where the water level is too high for common alfalfa.

In fact, the Grimm and Baltic alfalfas with their special selections are the hardiest, most desirable, most productive strains of alfalfa to be had.

On page 7 further description of Grimm and Baltic alfalfas will be found.

You are sure to get the Genuine Grimm and Baltic alfalfa when you buy the DISCO Brand Grimm and Baltic.

For Prices See Special Sheet Inside of Front Cover. 


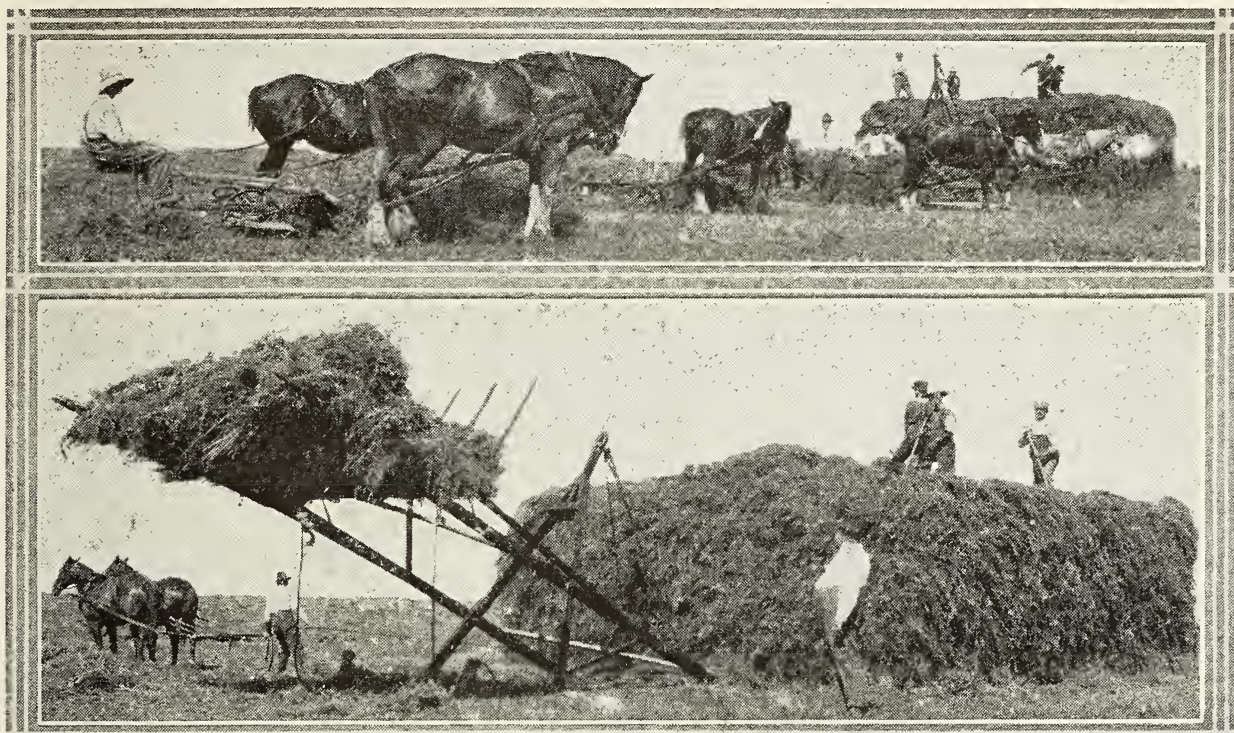

\section{Registered Alfalfa and Why}

\section{Sow 10 to $12 \mathrm{lb}$. of seed per acre}

The "DISCO Registration System" enables us to trace each individual strain of alfalfa to a definite single origin. Consequently only the most desirable native or acclimated stocks are DISCo Registered.

Alfalfa-lasts for several years (if you sow DISCo Registered Alfalfa Seed) while grain is merely a one year crop.

In order for alfalfa to come under the Established DISCo Registered heading it must have a known record of growth for ten years or more in the Dakotas or under equally severe conditions. Many of these DISCo Registered stocks have records of twenty-five years or more. This means the plant and seed are acclimated, and that you are not taking the chance of losing your crop by winter-killing when you buy DIsCo Registered Alfalfa.

\section{Registered Alfalfa}

DISCo No. 28 alfalfa without a doubt, heads the list of registered seed. It has been grown in southern Meade and Pennington Counties, South Dakota, for over thirty years, under most adverse conditions as to severe cold and drought

Some of the old fields are still producing excellent crops. It is a strong grower and develops a very strong crown and prolific plant. There is a very much increased demand for this seed every year. "Once Used Always Used" are the sentiments of the purchasers of DISCo 28. Our stock of this seed is rather limited this year but is of the usual good quality.

DISCO No. 38 is a close rival of DISCO 28 It has been grown in western Meade and Southern Butte Counties for over twentyfive years. We have distributed large quantities of this seed and especially favorable reports have come from Oregon and other extremely Western states where it is being used in drier regions without irrigation. You won't go wrong if you use DISCo
A seeding of DISCo Registered Alfalfa Seed will produce the desired results with a lesser amount of seed. Ten to twelve pounds per acre of the DISCO Registered Alfalfa invariably will give you a greater return than fifteen to twenty pounds of ordinary seed.

The advantage to buyers of DISCO Registered Alfalfa Seed is apparent. For example; you purchase some of our registered seed and sow it, you get fine results. You would like to get more of the same kind.

By means of our registration system and our method of keeping a careful record of all orders, and even though years have elapsed we are able to send you the same kind of seed.

\section{Well Established}

38. The quality of the seed is fine.

DrsCo No. 79 ranks well for third place It is a native alfalfa of the Black Hills region having a known record of over twenty years. Comes from the same locality as DISCO 28, and is doing well all over the country. It is a wonderful producer of both hay and seed.

DISCO No. 80. This stock is a native of Jones and Lyman Counties, South Dakota. This alfalfa is both drought and cold resistant to a marked degree. The acreage of this strain is rapidly increasing. We have a limited stock of this seed on hand, which is of good quality.

DISCO No. 26 is probably of Turkestan origin. It has been grown in the northern half of Meade and southern half of Perkins Counties, South Dakota, for the past fifteen years. It has stood the test and ranks well with the other registered alfalfas. Our stock of this seed is small, but of good quality. A good buy for the money. 


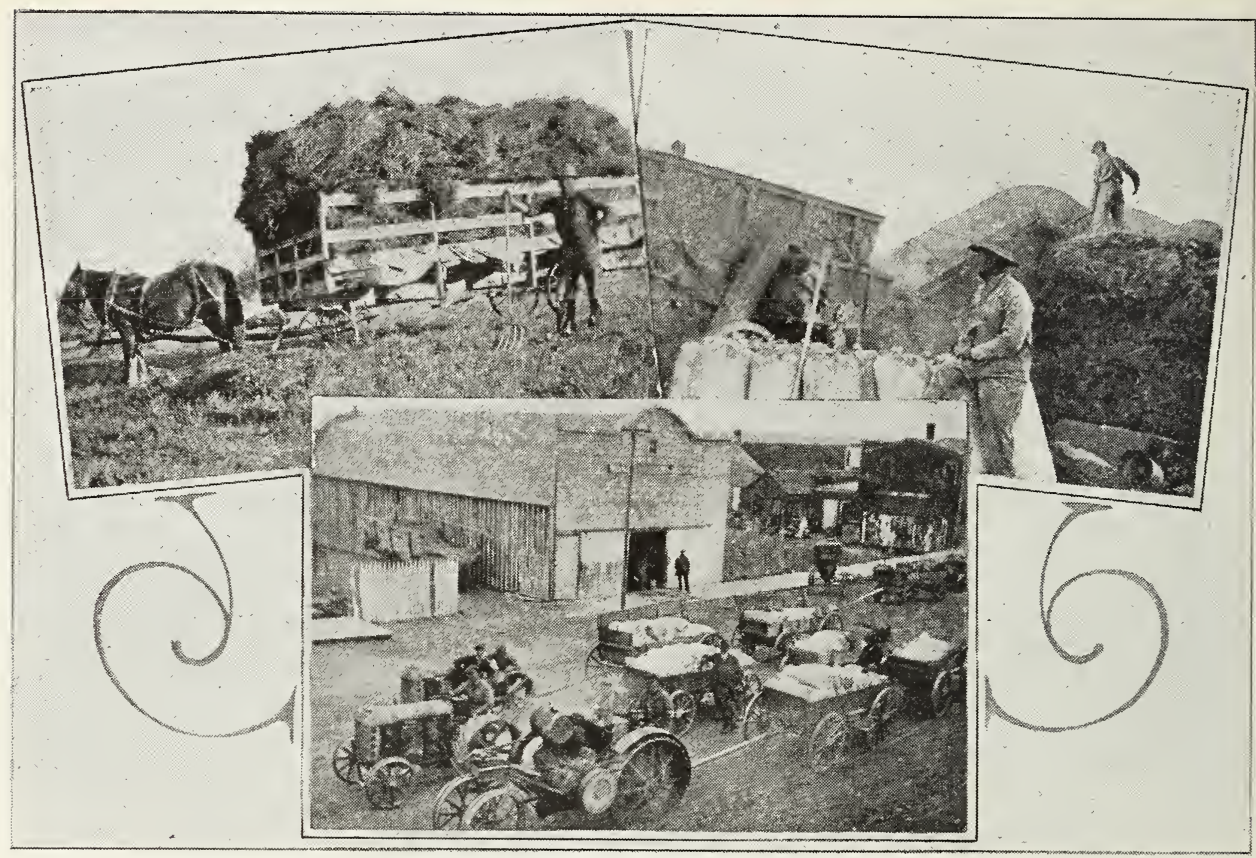

Modern Methods Used in the Hardling of Grimn Alfalfa in Westem South Dakota.

\section{Disco Pedigreed Alfalfa}

Over fifteen years have passed since the work of developing pedigreed strains of hardy alfalfa was begun by Prof. W. A. Wheeler at Brookings and Highmore Agricultural Stations, South Dakota.

As a result of this work there has been produced a number of strains of alfalfa that show a decided superiority over the common alfalfas as well as over the parent stocks from which the pedigreed strains were selected and developed.

When Prof. Wheeler organized the Dakota [mproved Seed Company in 1906 he continued the work of special plant selection and breeding of pedigreed alfalfas. This was the first work of its kind in the country and we know of no other commercial organization in the world conducting the kind of investigational work with alfalfà that we have done.

These pedigreed strains have found great favor with the agricultural colleges from Coast to Coast in the north half of the U. S. A and are worthy of your consideration because of their remarkable records of hardiness and production.

\section{DISCO 11C.}

From the Baltic-DISCo No, $11 \mathrm{C}$ has proven itself to be the hardiest of the hardy. This strain is a revelation in perfect and hardy alfalfas. It is drought resistant to a marked degree. Recovers quickly after cutting. An exceptionally large and free stooling plant yielding an abundance of leafy hay. For seed production it has a record of its own. On one acre where DISCO $11 \mathrm{C}$ was seeded in rows three feet apart it produced in 1917 two hundred and eightysix pounds of seed.

This alfalfa is no longer an experiment. Its native home was on the plains of South
Dakota. It is acclimated and is making a great reputation wherever tried.

If you want a field of alfalfa that is the talk of the country, a field that will produce you more than the ordinary amount of hay, a field of the hardiest alfalfa known, sow a few acres of the DISCO 11 .

\section{DISCO 19 A.}

The DISCO 19A is a special selection from the Grimm that excels its parent plant in many ways.

From the hundreds of individual trials carried on in our alfalfa nursery there were selected plants, which stood out distinctly as being heavy seeders, erect and strong in habits of growth and producing many leafy branches. Plants with a large productive crown, underlaid with a strong and spreading or branched root system. By special selection of this type of plant we have developed the worth while pedigreed stock of DISCO 19A, an alfalfa strain with a known parentage.

This pedigree selection from the famous Grimm alfalfa has probably been tested at more experiment stations in a greater number of states and over a wider area than any other strictly pedigreed alfalfa tracing back to any individual plant selection.

From a large percentage of these trials we have had full reports on DISCO 19A, and other alfalfas with which it has been tested. So far the reports received place DISCO 19A among the leaders for hardiness or production of either hay or seed.

The demand for this extra hardy and prolific strain of alfalfa is rapidly increasing. We have a limited stock of seed from this excellent pedigreed strain. It is going to move rapidly. Get your order in early. for what you need. 


\section{Grim Alfalfa-Survival of the Fittest}

The Grimm Alfalfa which has been grown for many years in Minnesota and the Dakotas, with excellent success, was brought from Wertheim, Province of Baden, Germany, in 1857, by a farmer named Wendelin Grimm. This variety has attained increased hardiness since its introduction into these states.

Natural selection or the law of the survival of the fittest, the strong branched root system, the immense spread of crown, underground buds, protected by the soil, has made Grimm alfalfa famous for its hardiness and productiveness.

It must be understood that all Grimm alfalfas that are offered on the market cannot be considered as a hardy variety for the North. Grimm Seed coming from Arizona or the South, while it might be genuine Grimm, would not withstand the rigorous winters of the North. Nor is all the northern grown alfalfa that is offered on the market as Grimm's really genuine Grimm.

At the present time there is a good acreage of the genuine Grimm alfalfa grown. The growers are very enthusiastic over its extreme hardiness and wonderful productiveness.

The following is an extract from the Farmers' Bulletin, No. 757, entitled Commercial Varieties of Alfalfa: "On account of its superior hardiness, Grimm alfalfa is particularly recommended for the northern part of the Great Plains region and all parts of the Northwest. It has also proved better able to survive the winters in the colder portion of the humid section of the country where winter killing is a serious factor. The supply of seed on the market is still rather limited and commands a high price. As a result unscrupulous dealers have offered for sale large quantities of common alfalfa under the name of Grimm."

Be wise. Keep this in mind. Purchase only the northern grown genuine Grimm alfalfa seed if you want to be fully satisfied. Being specialists in this line you can absolutely depend on getting the genuine Grimm when you buy DISCO Grimm.

\section{Disco-Baltic Alfalfa}

A comparatively new variety of hardy alfalfa, very similar to Grimm, and rapidly being established in the esteem of all growers.

In describing the Baltic alfalfa, the authorities of the U. S. Department of Agriculture, Bulletin No. 757, have this to say: "While the Baltic differs slightly from the Grimm, in some minor details, the two are so similar that it is seldom possible to distinguísh one from the other. This variety is recommended for sections where the ordinary strains suffer considerable loss through winter-killing. This includes practically the same territory to which the Grimm is adapted, that is, the New England States, the greater part of New York, Michigan, Wisconsin and Minnesota; the northern Great Plain states and the northern part of Pennsylvania, New Jersey, Ohio, Indiana, Illinois and Iowa. As in the case of Grimm alfalfa, the quantity of Baltic seed produced in the United States is rather limited and the same precautions are necessary in purchasing it."

The Dakota Improved Seed Co. are the promoters and breeders of the Baltic alfalfa. Therefore, when you place your order with them for this variety of alfalfa, you can rest assured you will get the original DISCO Baltic alfalfa seed.

\section{TESTIMONIAL LETTER}

Duvall, Wash., Mareh 13, 1919. Dakota Improved Seed Co.,

Dear Sirs:-

Enclosed find check for $\$ 7.50$ for which please send me some of your Grimm Alfalfa seed. I got some from you two years ago and it is doing fine. Send by parcel post to Duvall, Wash.

\section{Yours respectiully,}

\section{H. W. Chapman.}

\section{Testimonial from John Wm. Dallavo}

Morley, $\mathrm{R}$ 3, Mich.
The Dakota Improved Seed Co.,
Mitchell, S. Dak.

Gentlemen :-

With the "Alfalfa 28 " seed I bought of you last year, I have secured a perfect stand of Alfalfa on light sandy soil, and it is the only one in this neighborhood, for miles. Many attempts have been made to grow alfalfa here but none have suceeeded until this field was planted.

I credit much of the good results to the fine quality of seed obtained from you, and thank you for good stufi. The germination was marvelous.

Kindly send me your circular of prices as I shall want Alfalfa, Red Clover and Alsike seed this year, and it shall come from уou.

Also please let me know if you would eare to have me act as your agent in this community on a commission basis. I believe I could sell a good deal of your seed here. Not so much this year due to high prices, but more in the future.

Hoping to receive a prompt reply, I shall remain,

Most truly yours,

(Signed) John Wm. Dallavo. 


\section{Commercial Alfalfa Seed}

The term "Commercial Alfalfa Seed" is used in connection with the common Dakota grown alfalfa which does not come under our headings of DISCO Registered or Pedigreed alfalfas. Samples of the commercial alfalfa seed are marked South Dakota Alfalfa.

Dakota grown alfalfa seed has become recognized by the leading seed men as a distinct type. It is also a very popular variety with the experimental stations throughout the country. This fact is due to several things: the weather conditions in this state are unusually ideal for seed production; the wide variations as to heat and cold make a very hardy product. Ranchers of this state and especially those west of the Missouri river have combined the culture of alfalfa with livestock, many of them maintaining vast fields for hay and seed, and many of these fields have been long established.

Dakota alfalfa seed has made an enviable reputation in the northern states because of its general hardiness; seed from this state being much higher priced because of the additional value coming from greater hardiness.

We especially recommend Dakota alfalfa for northern planting and are specialists in this line. This seed not only comes from fields long established, but from altitudes varying from two to three thousand feet and from semi-arid regions. The plants are compelled to undergo a natural selection or the survival of the fittest, and the seed has inherited the tendency to become vigorous to a very marked degree. There is absolutely no questioning the past performance and the present worth of Dakota alfalfa.

\section{Our Grades of Commercial Seed}

Much care is used in the purchase of all of our field seeds. In the cleaning and milling process two grades are established -our DISCO brand and the Emerald brand. We might quote on one grade only by blending the two grades but prefer to keep the highest possible grade as our DISCO brand, which must meet the requirements of any state or national test, be clean, plump seed, of good color, according to the season, and of high germination.
The Emerald brand is a very good grade, in fact, is equal to many of the so called best grades often sold. The difference between the real value of this and the DISCO brand is often only one of appearance instead of a real difference in quality.

You always get your money's worth when you buy the DISCO or Emerald brand field seeds.

\section{Purity---Germination Insurance}

All our stocks of seeds are sampled to the State and United States seed-testing laboratories before shipping. The results of these tests are used as a basis for the report on the purity and germination tag which is attached to every shipment of
DISCO and Emerald brand ficld seeds.

These tags cover the requirements of the seed laws of all the States. Every purchaser is thus assured of an accurate statement of the quality of his seed. 


\section{Essential Points in Growing Alfalfa}

1. Select a well drained, well prepared, well settled seedbed, the richer the better.

2. Be sure the seed is hardy, well cleaned Northern grown seed. Don't use seed from unknown or questionable sources.

3. Caution: Be careful not to cover the seed too deep. From $1 / 2$ to 1 inch is sufficient. In drilling in BE CAREFUL. In sowing broadcast, harrow lightly.

4. Seeding may be done any time from April to September. Using from 8 to 20 lbs. of seed per acre.

5. Mucl good may be derived from adding lime to the soil and inoculating the seed. In many localities both are necessary. In this state it is not practiced to any extent. So do not become confused in thinking the culture of alfalfa requires a college education.

6. Best to treat an alfalfa field with care when it comes to pasturing the first year. Wait until the seedbed is well firmed and the root system well established.

7. Don't give up. Many well known growers have succeeded only by staying with it.

Our Manual "Growing Alfalfa Successfully" treats further on these topics. Write for your free copy.

\section{It Pays to Inoculate Alfalfa}

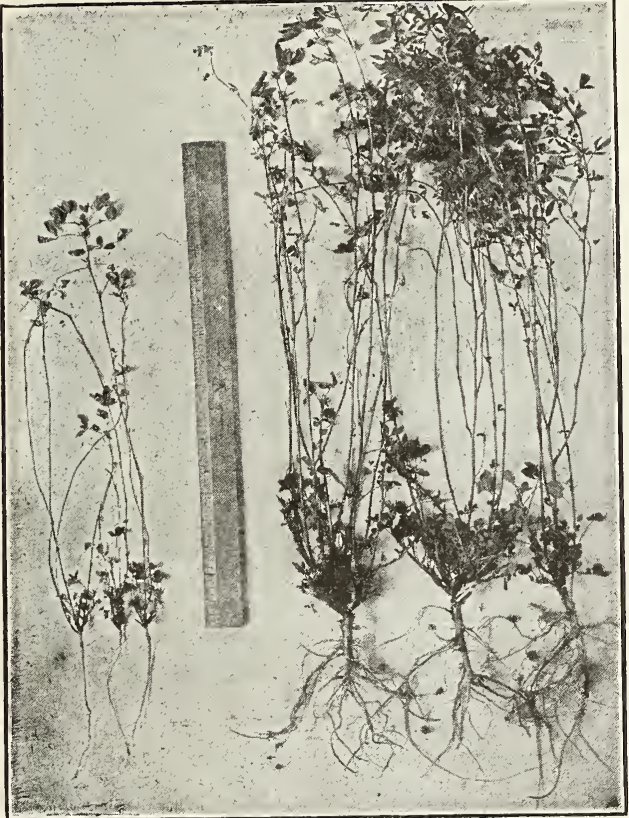

Alfalfa plants from different portions of the same field, those on the right from seed inoculated with Legume Bacteria Culture, those on the left from the same kind of seed not inoculated. The ruler is 18 inches long. Notice the stocky growth, the thick, sturdy roots, and nodule clusters on the inoculated plants as

compared with the weak growth of the others.

All authorities on the subject advise inoculation of the seed or of the soil by various methods. It is rather costly to inoculate the soil, considering the labor in transporting the soil from a neighbor's field and spreading it over the soft seedbed. It is so much easier to treat the seed rather than the seedbed, either by the Glue Method or better yet, with a pure culture, at a cost of from $20 \mathrm{c}$ to $30 \mathrm{c}$ per acre, depending upon the amount of seed sown.

Inoculation places the nitrogen-fixing bacteria where they are needed and absolutely necessary for a perfect stand. In old alfalfa growing districts that are fitted naturally for the growing of alfalfa the soil already containing lime and bacteria, further expense in this regard is useless. This condition prevails in much of western South Dakota, and in fact, a large portion of this state and many other western states. In most of North Dakota, Minnesota, Iowa, Missouri, and states east of these, very marked results are often secured from inoculation by pure culture.

We carry in stock only pure cultures from alfalfa put up for us in the most approved form by prominent bacteriologists, and can be relied upon to accomplish the desired results.

Prices: Culture for one bushel or 60 lbs., $\$ 1.20$. Five cultures or enough for 360 lbs., $\$ 4.50$.

Forest City. Ia. Jan. 7, 1918.

Gents:

The Iowa State College referred me to you for genuine Grimm alfalfa seed. Yours resp., Hans J. Helvig.
Dakota Seed Co.

Fowlerville, Mich. Mitchell, S. D. Gentlemen :

Our Agricultural College referred me to you as a reliable firm where Grimm alfalfa can be obtained. Yours,

H. G. Aldrich. 


\section{Sweet Clover no Longer a Despised Weed}

Sow from 12 to 20 lbs. per acre.

For many years we have observed sweet clover, melilotus or bee clover, as it is often called, growing voluntarily under adverse conditions, by the roadside, in fence corners, along the ditches in irrigated sections and on unoccupied lands in nearly every state. It has been commonly considered as a weed and a great nuisance but in spite of the prejudice against it, and misunderstanding regarding its agricultural values, many experiments have been conducted within comparatively recent years to ascertain its adaptability, feeding value, and effect upon the soil which definitely determined its importance as a farm crop.

White blossom sweet clover is a biennial, that is, lives but two years unless the seed crop at the end of the second year is allowed to form and scatter. For this reason, sweet clover is well adapted to fit into crop rotation. Many prefer the white blossom variety because it is a very rank grower and excellent for pasture. There are those, however, who will sow only Yellow Blossom (melilotus officinalis) claiming for it earlier yields, a finer quality of hay and the seed is usually lower in price.

Its adaptability to soil and climatic conditions are particularly a strong feature in its favor. It will endure greater extremes of temperature and grow on soils too poor for alfalfa and under conditions where other grasses failed to produce a crop before it.

For an all-around money crop, hay crop, pasture crop, or soil-builder, sweet clover is a wonder. Therefore, before you condemn it, consider the following facts:

1. It is not a weed.

2. Like alfalfa it is rich in protein.

3. It will not bloat cattle or sheep.

4. Equal to alfalfa for pasture.

5. It is a great milk-producer.

6. Furnishes early spring pasture.

7. Fits well in crop rotation.

8. Is a great soil enriching crop.

9. Is a valuable plant for honey-bees.

10. Prepares the soil for alfalfa.

11. Roots are soft and give no trouble in plowing.

12. Roots being tender become inoculated more readily than alfalfa.

13. Never damages cultivated crops.

14. Its roots decay rapidly adding $\mathrm{much}$ nitrogen and humus to the soil.

15. Grows and will produce a crop in all parts of the United States.

16. Seeds freely in both humid and dry sections.

17. Will grow under conditions where clover and alfalfa fail.

(a) On land too low, too wet or too alkali for alfalfa.

(b) On land too hard and compact for alfalfa.

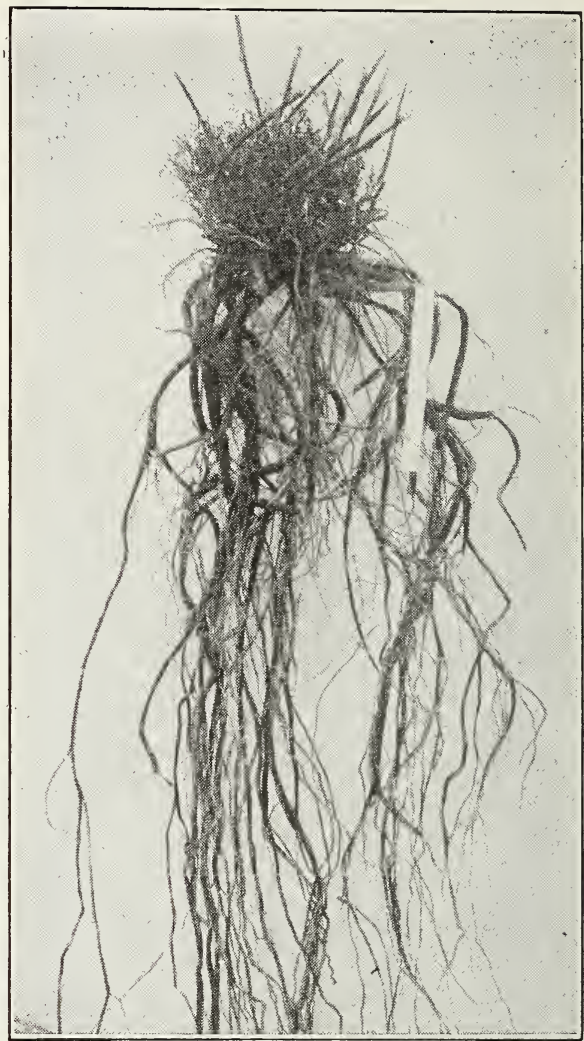

Nole kixtensive Root system.

(c) On soil too poor for alfalfa, especially where there is no lime.

Credit is due Mr. P. G. Holden, Director Agr. Ext. Dept., I. H. C. of New Jersey, Harvester Bldg., Chicago, for the foregoing facts.

Use a nurse crop or not with sweet clover. Sow very shallow in a well prepared seedbed. Early spring-even when there is a light skiff of snow on the ground is the best time to sow sweet clover.

\section{SCARIFIED SEED.}

Scarified Seed. Probably there are more hard seeds found in sweet clover than in other clovers or alalfa. This percentage can be greatly reduced and the actual percentage of germination by test brought up a great deal by scarifying the seed. We have found from experience that scarifying sweet clover seed is so valuable that we are scarifying all our hulled seed, for which we make no extra charge. For spring seeding, scarified seed is much safer to use than unscarified. 


\section{What Kind of Clover or Legume Shall I Grow?}

It is plain that a shorter-lived legume than alfalfa is needed to fit into shorter rotation to help keep the soil in condition. Of all the annual and biennial legumes which have been tried, none proved more profitable than the white flowered sweet clover. Furthermore, none leave the soil in better condition for the following crop than this same sweet clover. The roots penetrate deeply and widely, forming a network and mellowing the soil at less ex pense than any mechanical form of subsoiler or tiller. We know very well that there is no profitable permanent agriculture or continuous farming possible without clover of some kind or at any rate without a legume crop of some kind.

Sweet clover has been known for generations as a roadside weed but only in recent years has its value been recognized by progressive farmers. Today, it is a well recognized field crop in many states and has a special agricultural value in every state where common red clover frequently winter-kills or fails to produce a satisfactory crop. Even in states like Iowa, where red clover is the leading crop, the sweet clover is becoming popular because it can be pastured without danger of bloat and can be fed as dry hay with less danger than red clover since it has a smooth stem and does not throw off the disagreeable dust made up of fine hairs that the red clover is noted for.

\section{WHAT TO DO WITH SWEET CLOVER.}

The most common uses to which the crop may be put are: hay, seed, pasture, bee range, and green fertilizer.

\section{FOR HAY.}

It will produce two or three crops of hay with a yield of from one to five tons per acre depending upon soil and moisture conditions. It is imperative that sweet clover hay be cut on time and that means before it blossoms much. When it begins to bloom the stalks become coarser, the fiber becomes woody and the space between the leaves lengthens. All these things render the crop unpalatable and difficult to work with.

There is also a bitter substance known as cumarin in the plant. When stock first taste this, they do not like it, but after becoming accustomed to it, they eat it readily, as it has no harmful effect.

\section{FOR HAY AND SEED.}

With present prices of seed there is a first rate opportunity to make a profit from seed production. In favorable seasons, the crop frequently makes from six to eight bushels of clean seed per acre.

If seed is desired, the first crop should be cut for hay the same as before. The second may then be permitted to go to seed. The second crop usually makes a finer growth and bears a better seed crop and is more convenient to harvest and handle than the first crop would be if permitted to go to seed. (Credit is given Prof. Manley Champlin, of the South Dakota State College for the above.)

We are making a specialty of Sweet Clover this year and have a large supply of extra select scarified white blossom sweet clover. For a short crop rotation, and a soil builder, carefully consider sweet clover. Prices on alfalfa and red clover are very high. Sweet Clover prices very moderate. Therefore, take advantage of this golden opportunity to get the clover that fits so well in crop rotation and makes the most excellent pasture and hay.

Dakota Improved Seed Co.,

Oacoma, S. Dak. Mitchell, S. Dak.

Gentlemen:

I am inclosing an order for seed which you may forward by express to oacoma, $S$. Dak.

I wish to state that the seeds which we purchased of you last year were very satisfactory indeed. They were true to name and all lived up to their germination test. Very truly yours, J. A. Wheeler. 


\section{Riverview Special}

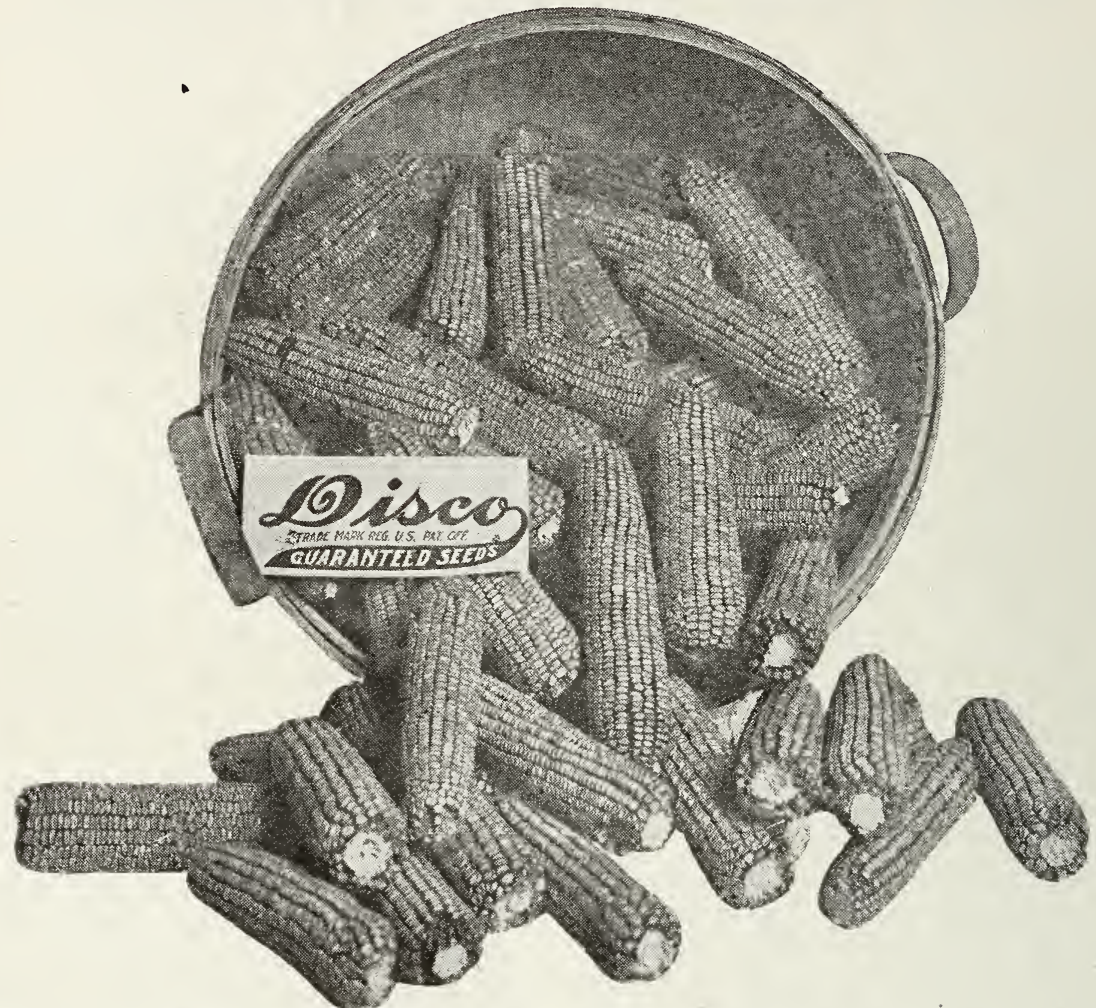

Without a question Riverview Special is one of the best 90 -day yellow dent varieties of corn offered on the market. It has been developed, not for the largest type of corn but for the hardy characteristics which predominate. The ears will average $8 \frac{1}{2}$ inches in length with a girth of 7 inches, with 16 to 18 rows well carried out at butt and tip. The shelling percentage of this corn is around $95 \%$. The dent is on the dimple order, pronounced and yet not too rough. The color is a rich yellow, grain moderately deep, and of smooth handsome appearance. The ears are well formed, uniform and with a moderately strong shank. The field characteristics are in its favor with leafy stalks, which attain a height of $7 \frac{1 / 2}{2}$ to 8 feet, with numerous brace roots. Yields of from 40 to 60 bushels per acre are not uncommon.

Riverview Special thoroughly matures in 90 days but 95 days will perhaps be a safe average. This makes an all-around dependable variety of corn where early frosts are common. The southern half of South Dakota, Minnesota, Wisconsin and Michigan and the north half of Iowa and Illinois cover fairly well the territory best suited for Riverview Special. It may also be used to advantage to drill in early in June for ensilage or fodder. Three large silos are filled on Riverview Ranch each fall with Riverview Special. It fills the bill and suits us as well as our customers from whom we have numerous testimonials on file. We have a large supply of this corn on hand, showing a good germination. You will not be disappointed if you order Riverview Special.

$\begin{array}{lc}\text { Disco Seed Co., } & \text { Mitehell, S. D. } \\ \text { Dear Sirs: } & \text { 12-28-19. }\end{array}$

Four years ago, I selected from your varieties of Corn, the Riverview Special, for the first reason, because it was bred for this locality, second for its deep grain and rich yellow in color and now I would recommend this corn by far, ahead in shelling percentage of any Corn I have ever raised or heard of, the poorest quality of this I ever raised shelled out $96 \%$ and this season I had some that graded almost No. 2 and this shelled out $102 \%$, and $I$ say it's an advantage to the corn growers of the Northwest to have someone interested in breeding this corn to that high a standard as did the Disco Seed Company.

Please send me your catalogue as I am interested in seed oats.

Yours truly,

(signed) S. .J. Supalla. 


\section{Disco 90-Day White}

Equal in quality, yield and fully as early as Minn. 13. It is especially valuable for silage purposes having a leafy stalk.

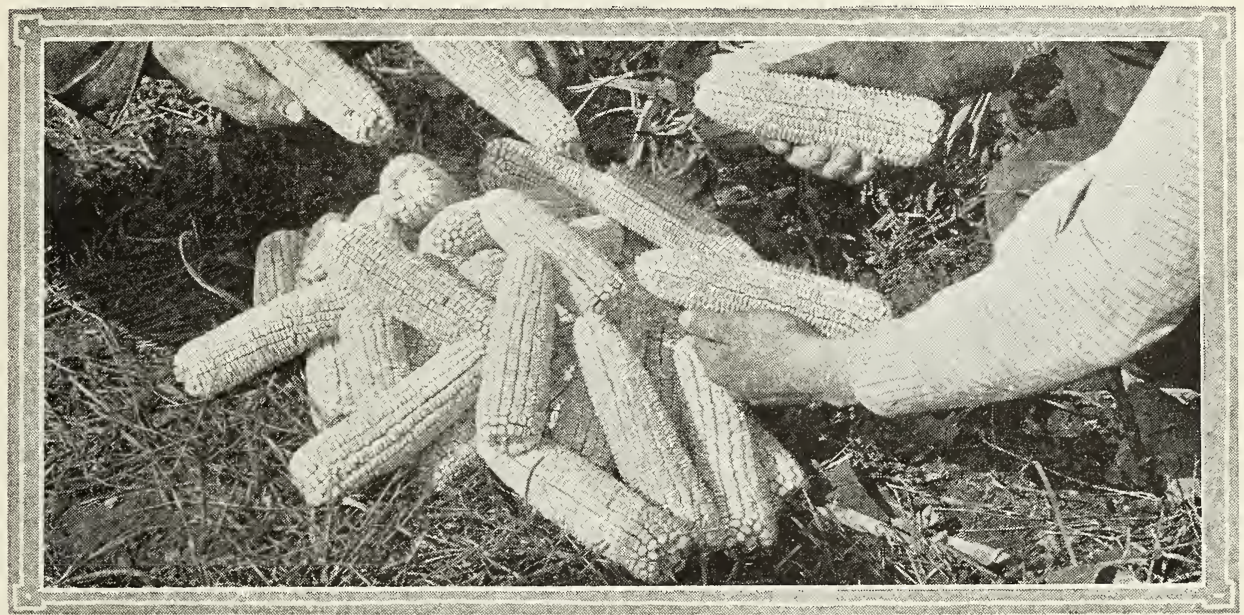

DISCO 90 Day White Dent.

The DISCO 90-day White Dent Corn has met the approval of more growers of White Dent Corn than any other strain of White Corn. For early ripening, great yield and compact growth of ears, it is one of the best. Besides being early the ears are good size and the kernels deep and well shaped. DISCO yo-day White is admirably adapted to a northern climate. The stalks attain an average height of about 8 feet, while the ears shoot out at about $3 \frac{1}{2}$ feet from the ground.
The above photograph shows the hands of two well satisfied growers of DISCO 90day White. Note the type of ear they are selecting for seed. Such corn as this can easily be recommended for Northern Iowa, Illinois, Central South Dakota, Minnesota, Wisconsin and Michigan. It will undoubtedly mature north of this line, with care, the first season in saving the seed until it is acclimated to a more northern season. We have an excellent stock of specially selected 90 -day White. Get your orders in early for the extra select stock.
Kadoka, S. D.

Disco 90-day White Dent corn is the earliest and the best drought resister I have seen. Your seeds are the best I used this year and I like your way of doing business better than most seedsmen.

Lewis Stephens.
Kennebee, $\mathbf{S}$. D.

This is my third year sending for my seeds from your company, and can say that I have been more than pleased with all the seeds I have ordered for I do believe that every seed whieh I planted from your house has grown. I shall use no other as long as I ean net your seeds. Yours sineerely, Mrs. Henry L. Peyton. 


\section{Minnesota No. 13 Corn}

Since its introduction by the Minnesota Experiment Station in 1896, Minnesota 13 has been distributed across the United States and is well known everywhere as an early, worth-while yellow variety of corn. It is considered to be the best early yellow type; ears larger in size than Pride of the North as produced in the Corn Belt, and fully as early.

In yields, records have been attained as high as 90 bushels on clover sod. In Minnesota and the Dakotas the average is close to 50 bushels, which is very conservative.

The ears contain 16 to 18 rows of rich yellow grains, have a good shelling percentage, well filled butt and tip and a small shank in favor with the husker.

In our strain of Minnesota No. 13 we aim to retain the earliness of the true variety by obtaining the seed for our own planting either directly from the Minnesota Experiment Station or from one of their accredited growers each year. We thus preserve the type of the experiment station as nearly as possible, which would not be the case if we continued to raise this variety in the vicinity of Mitchell or south of here from the same stock year after year.

One field near Mitchell produced good ripe corn in 87 days from the time it was planted. It is safe to depend upon Minnesota No. 13 in 90 days any year. We have a large supply of fine quality Minnesota No. 13 which is sure to please you.

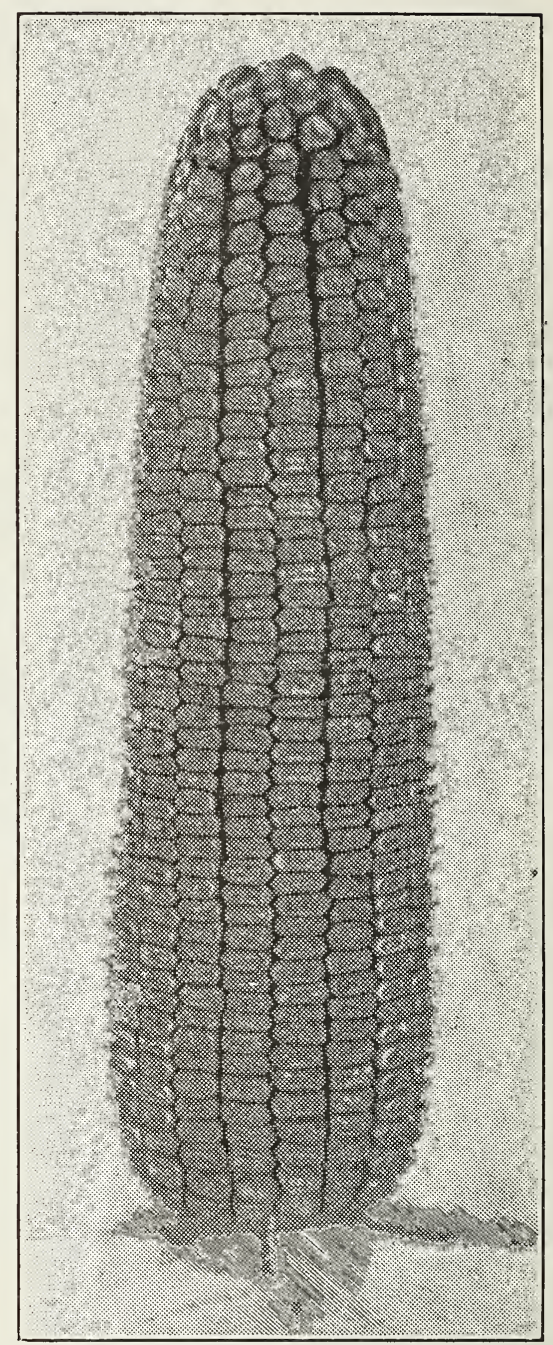

Minnesota No. 13 Corn.

Alzada, Mont.

I have bought seeds from you two seasons, once while in $N$, Dak. All have proved to be of high germination. Your method of doing business has been satisfactory to me-filling orders as far as possible promptly and not delaying the whole order on account of being short on a fevw, and then forvarding shortage at the earliest possible time.

Fred J. Engel. 


\section{Disco-Murdock Corn}

\section{Exceptionally Good 100-Day Variety for Northwest}

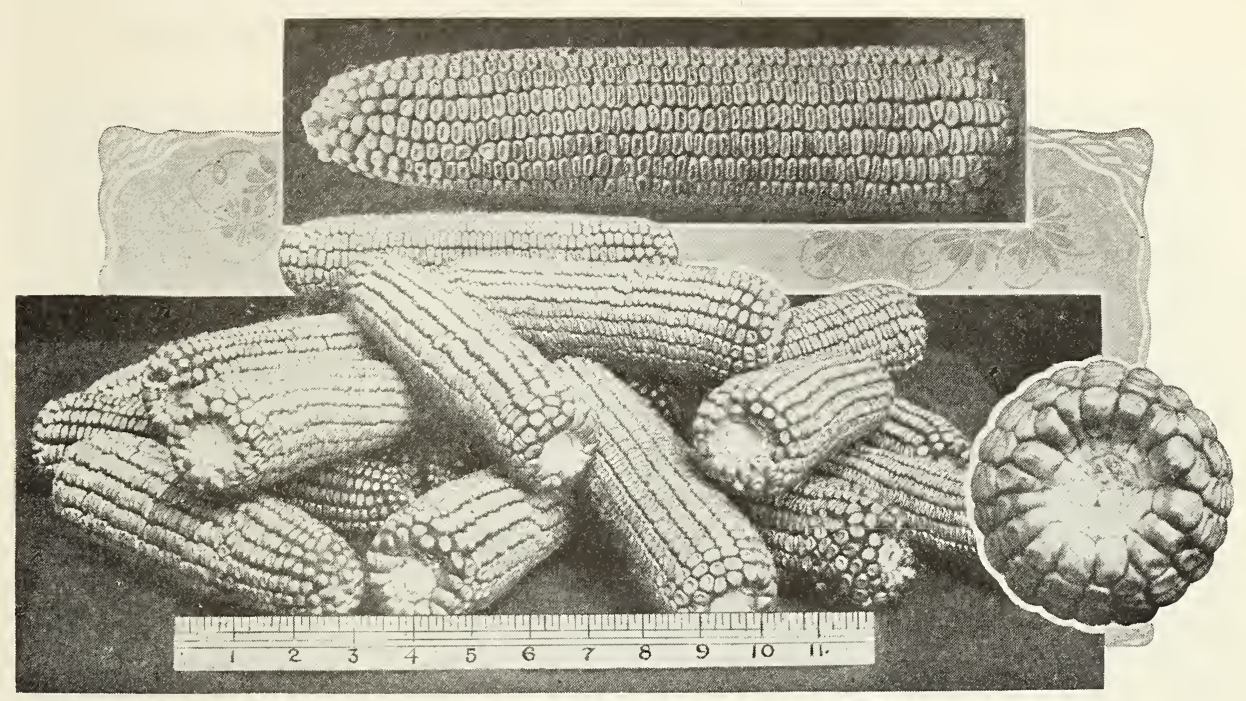

Disco Early Murdock

A variety very similar to our Riverview Special in color, size of ear and general make-up. The ears are well formed, shell off a large percentage of corn, the kernel is deep and with a large germ. We recommend Early Murdock for all parts of northern Iowa, central and southern Minnesota, southern and central South Dakota, northern Illinois, southern Wisconsin and Michigan.
It is considered one of the most productive and as early as any of the deep kernel varieties. It is well established in type and is growing in favor with those who know it. It is one of the most dependable of the later varieties. The stock attains a growth of from 6 to 8 feet high. It is a stout, stiff stalk which stands well in storms. The ears are borne well up on the stalk. It almost invariably yields well and with good care and favorable conditions will give a very large crop.

\section{Wimple's Yellow Dent}

Another prize winner and a variety recognized as standard in the north half of the Corn Belt. Has been grown for a number of years in southeastern South Dakota close to the boundaries of Iowa and Minnesota. Won the northern zone sweepstakes at the National Corn Exposition in 1907 against all comers from the northern states.
The size of the ear is surprising, an average ear measuring 9 to $9 \frac{1 / 2}{2}$ inches in length, $61 / 2$ to 7 inches in girth and containing 16 tc 18 rows weighing 9 to 12 ounces. Its season is suitable to southern Minnesota, southeastern South Dakota, most of Iowa, northern half of Illinois, southern half of Wisconsin and other localities having similar seasons.
The Early Murdock is a good corn for this country. It will ripen here if it has half a chance. This has been a very poor year with us for corn, but last year I planted some June 10th. It did fine and got ripe early, J. D. Vroom, Howard, S. D.
You sent me one bushel of Early Murdock corn, it grew good and is the best crop I ever raised.

For Prices See Special Sheet Inside of Front Cover. 


\section{Disco Pride Corn}

\section{An Improved Strain of Brown County Yellow Dent}

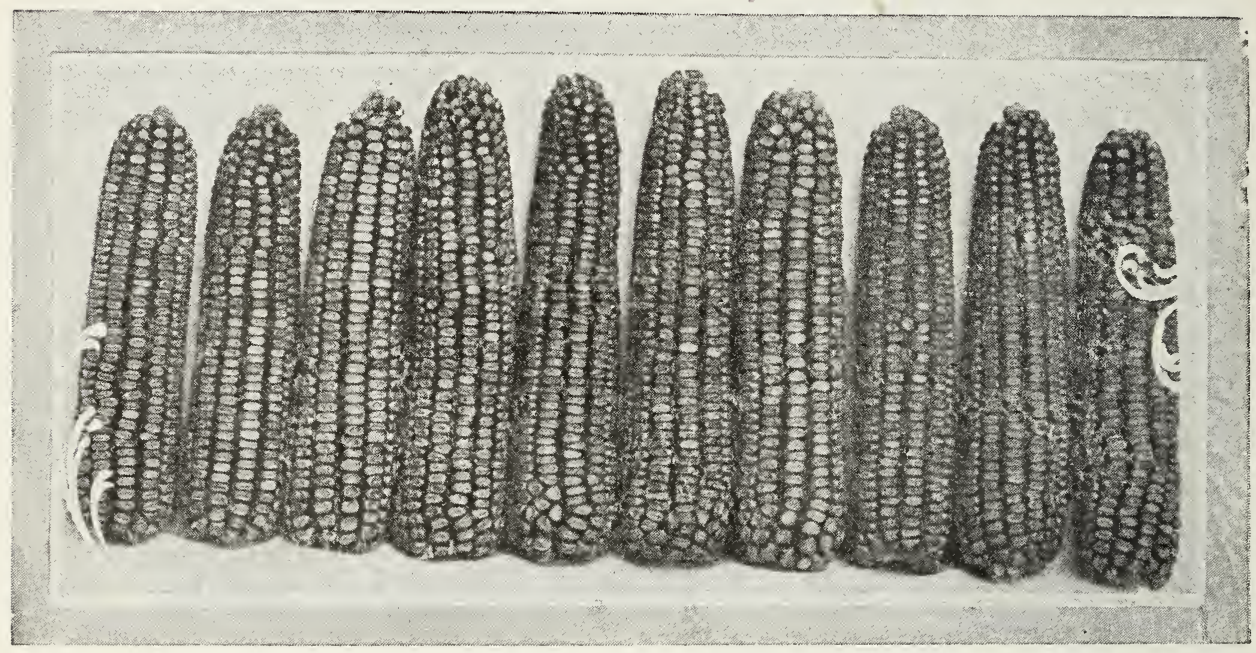

\section{Disco Pride.}

In 1906 we first ran across a variety of corn in Brown County, So. Dak., which had made a good record for yield and earliness. It has been grown there and has matured satisfactorily every year for the past eighteen or twenty years. It has been tested at the Highmore Experiment Station where it yielded between forty-five and fifty bushels per acre. In 1907 , at the same experiment station, this corn outyielded all other varieties and showed a drouth resistance second to none. In fact, there was no corn at the Highmore Station in 1907 that was nearly equal to this in resisting dry weather. In type it resembles the Pride of the North and North Dakota Golden Dent.

The original stock of Brown County Yellow Dent as we secured it in 1906 had not been selected for uniformity of type or color. The improved strain which we offer as DISCO Pride shows a great improvement over the original. It retains the extreme earliness of the original strain, but has a better type of ear. There is still some variation in color and shape of kernel, but this does not injure it in any way when it comes to producing a good yield of corn under adverse circumstances. We believe that the DISCO Pride corn planted in the northern part of South Dakota, North Dakota or Montana is as safe a proposition as anything in the way of corn that can be secured. Corn-growing in Montana is just in its infancy. We have been furnishing this variety of corn to our Montana customers for several years and have the most favorable reports from it.

One of the strong features of DISCO Pride is the deep kernel and small cob. which makes this variety shell more corn in proportion to the size of the cob than most other varieties grown in the West.

We have a good stock of Davison County, So. Dakota, grown DISCO Pride on hand this year. This corn is good type, good germination and an ideal corn for northern territory.

For Prices See Special Sheet Inside of Front Cover. 


\title{
Northwestern Dent
}

\author{
Earliest of all Dent Corn
}
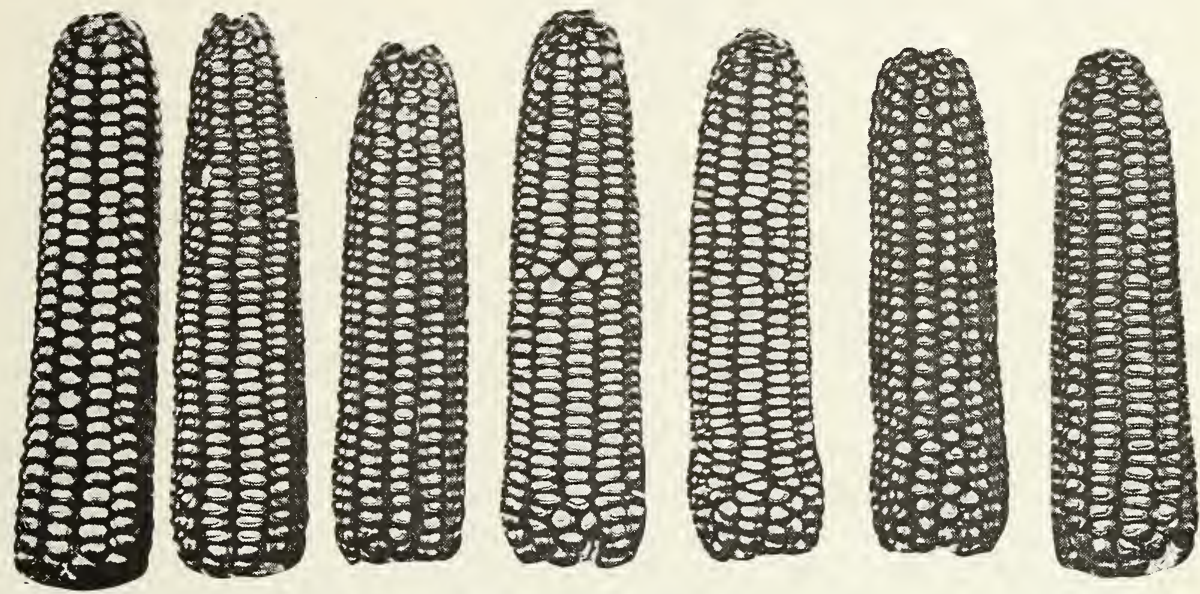

Northwestern Dent.

This corn is the result of a cross between an early yellow dent and a red flint, producing a type suitable for northern North Dakota, Minnesota and Montana. In fact it has ripened in Canada where even early sweet corn is an uncertainty.

In North Dakota this corn is grown perhaps more largely than any other one variety. It is extremely early and hardy in North Dakota and northern South Dakota. No other variety seems to have given the uniformly satisfactory returns in North Dakota in comparison with Northwestern Dent.

It is extremely early and readily adapts itself to various soil and climatic conditions. While on record as having matured a crop in less than 80 days, it is safe to count on the Northwestern Dent as maturing in 85 to 90 days, and when conditions are very favorable, even earlier.

The stalk is smaller and shorter than some of the later varieties attaining the height of 7 feet on an average. The ears are well formed, well up on the stock. The size of the ear is remarkable, all things considered. They will average 8 inches in length with 14 rows of kernels. In yield Northwestern Dent is a sure cropper and a worth-while variety, both for the extreme Northwest and for the Corn Belt.

For the Corn Belt, this early variety fills a very useful place in the early feed list. A few acres of Northwestern Dent planted along with the main season crop will produce an abundance of early feed, fully two to three weeks in advance of the later varieties. For early hog feed and especially for hogging-off, with rape sown between the rows at the last cultivation, Northwestern Dent is a very popular variety.

Under unfavorable spring conditions, when replanting is necessary, Northwestern Dent will deliver the goods. Under ordinary conditions this corn will ripen before the hot drying conditions of midsummer prevail. It is in truth a drought resisting variety.

In order for us to maintain the earliness of this variety we have our seed stock grown for us year after year in North Dakota.

The seed. we are offering this year is from that source. In buying Northwestern Dent from us you are sure to get the early maturing kind. 


\section{Disco Flint Corn}

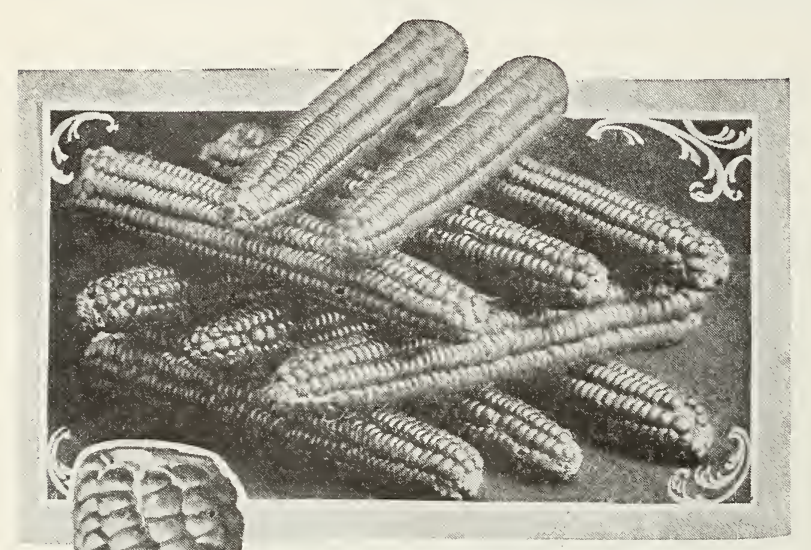

Disco Flint Corn

There is always a large demand for flint corn in all the Northern states and Canada. The various types of flint corn vary somewhat in earliness and yield, but all of them seem to possess the ability to mature a good crop of corn under adverse conditions. In the Northwest flint corn is largely used as a crop for "new breaking." It is also much used for late planting, where early crops fail to grow or for any reason the crop cannot be planted until late in the season. In this latitude it can usually be depended upon to produce good corn if planted as late as the 4 th of July. Flint corn is a very good type of corn to plant where the crop is to be fed in the field. It may be planted either alone or with other forage crops for this purpose.

DISCO White Flint. White Flint or Flour Corn as it is sometimes called, is becoming more and more popular each year. It is pearly white in color, the ears have from 8 to 10 rows, length of ear from 8 to 12 inches; kernels broad and blocky. From one to three ears are borne to each fine leafy stalk. The stalk is from 4 to 6 feet high, depending on the season, and the ears are from 8 to 20 .inches from the ground. Matures corn with a very small amount of moisture. Is well adapted to high altitudes and northern latitudes.

Gehu Flint. The earliest variety of flint corn and the earliest variety of any kind of corn. Adapted to the most northern localities. Ears small and low-down; color of kernel light yellow. The seed we are offering is grown from strictly northern grown "seed stock" from the extreme North. The quality and germination are good. If you have short seasons and can't grow other late varieties try the Gehu Flint. It will mature if any corn will.

DISCO-Squaw Corn (85 days). A very early "Native"-variety, having kernels all colors of the rainbow. A very beautiful corn and one that is very popular for late planting. The ears are larger than the Gehu but smaller than the DISCO White Flint. It is corn of quite high yield and good quality. A splendid corn in every respect. 


\section{Corn for Fodder and Ensilage}

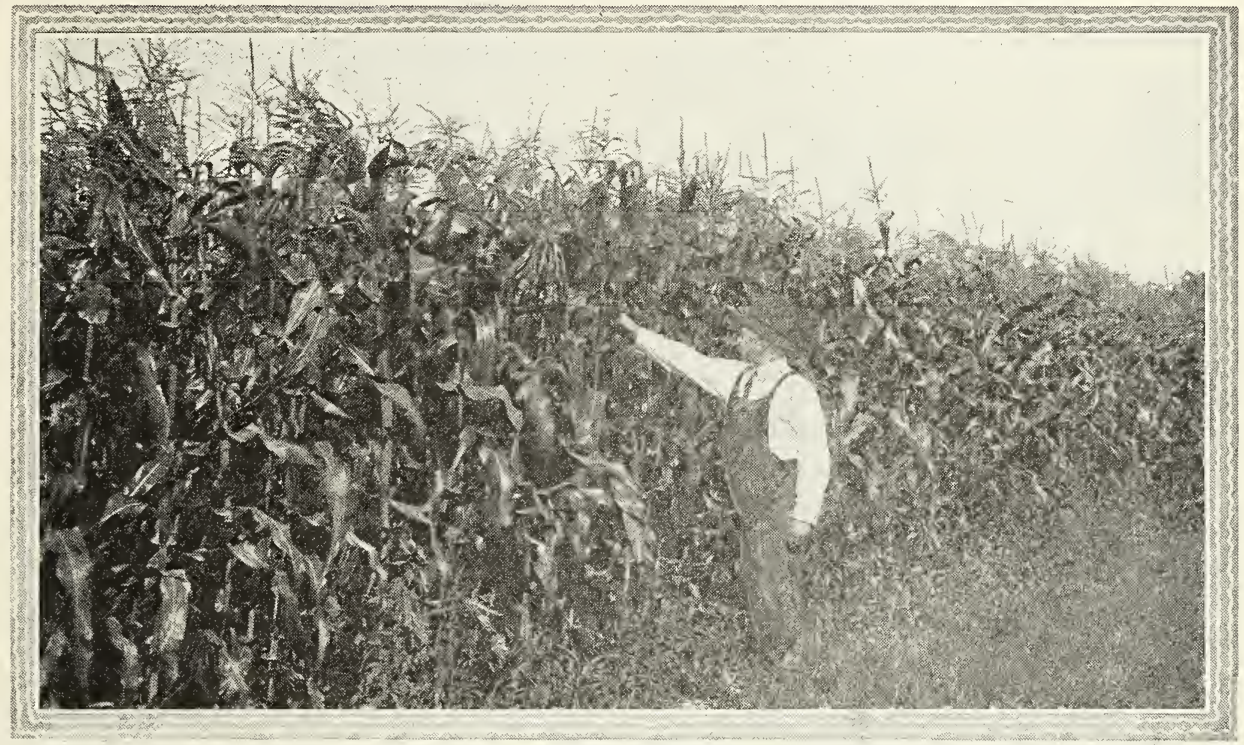

DIsco Medium Fodder.

A progressive system of farming cannot be a one-sided affair, but must embrace all possible methods of reaching best results. The farmer with large numbers of cows, horses, and hogs, the dairyman and stockman, must rely more on corn as an absolute pollcy of economy in feeding.

Dry fodder corn is probably the most satisfactory substitute for hay; in feeding value it is nearly equal to timothy hay, ton for ton and will produce from three to five times as much feed per acre.

Fodder corn drilled in rows $3 \frac{1}{2}$ feet apart using from $1 / 2$ to 1 bushel of seed corn per acre will usually produce from 12 to 15 tons of green fodder per acre. If one desires the fodder to be of a coarser nature, 12 to $15 \mathrm{lbs}$. of corn drilled in will be sufficient. By putting in this amount, the corn will naturally produce more grain.

DISCO Early Fodder. An early yellow or white dent corn producing a medium size leafy stock. Some prefer this instead of the larger varieties as it ma- tures earlier, the stalks are finer, more easily handled with the corn harvester, cures more readily and gives well formed ears.

DISCO Medium Fodder. About a 90 to 95 day corn, producing a large leafy stock from 7 to 8 feet in height. It will form a good ear thus adding to its feeding value.

\section{EVERGREEN SWEET CORN FOR FODDER.}

All varieties of Sweet Corn possess ever so much more "sugar" than feed corn. This is most important, for corn or feed containing this element in any quantity is naturally of great value. Evergreen Sweet Corn for fodder grows a leafy stock 6 to 7 feet in height and makes well formed ears, and yields a large amount of succulent fodder per acre. Drill in from 1 to 2 bushels of seed per acre in rows far enough apart to cultivate. Our stock is limited on this variety so get your order in early. 


\title{
Forage and Soiling Crops
}

\author{
Dakota Early Amber Fodder Cane
}

So successful has been the growing and ripening of Early Amber Fodder Cane in the Northwest that it is becoming more and more an indispensable crop. The Dakota Early Amber Fodder Cane is the earliest of all canes and will mature and produce seed in from 80 to 90 days.

The Dakota Early Amber Fodder Cane fills the particular want in the feeding ration. It is a very leafy desirable type for the North. Drilled in with Early Fodder Corn it makes the most excellent silage. Cane alone is greedily eaten by stock and they fatten and flourish on it. Dairy cows show a marked increase in milk flow when cane is fed as part ration.

\section{Big in Yield.}

The stalis grow from 5 to 6 feet in height and are very sweet. Yields of from 12 to 15 tons of green feed per acre. are not uncommon. It can be sown or drilled in using from 40 to 60 p.ounds of seed per acre.

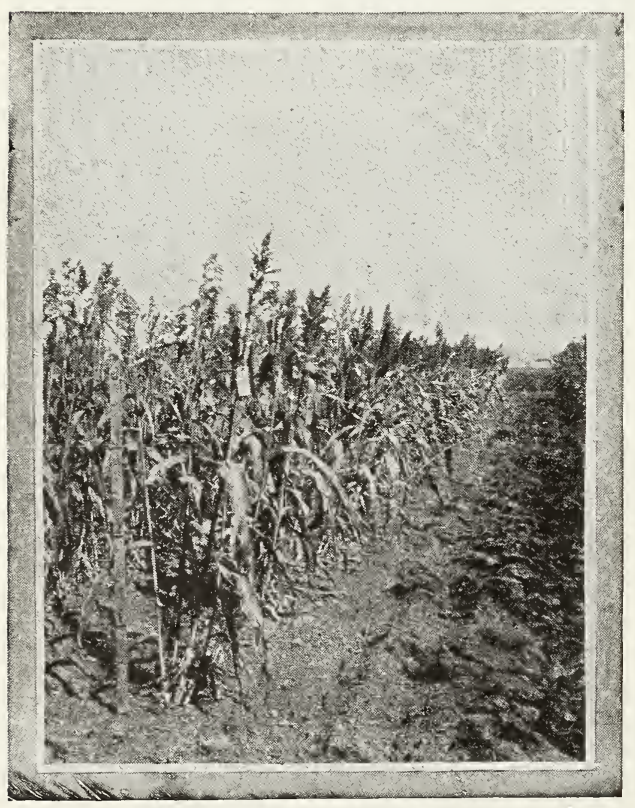

Dakota Early Amber Cane.

\section{Southern Grown Fodder Cane.}

This variety does not mature so rapidly as the Dakota Amber Cane, but the yield is very much heavier. When cane is grown for fodder alone the southern grown cane will produce a greater amount of fodder. It is sweet and palatable, and a very desirable feed for dairy cows and sheep, in fact all kinds of livestock eat it readily. It can also be sown thick and used to a good advantage for pasture for cattle, hogs or sheep. This variety is not suitable for sorghum syrup when grown in the North. Sow from 40 to 60 pounds of seed per acre.

Dakota Amber Sorghum Cane.

The earliest, richest and altogther the best sorghum cane for the North. In fact the only variety which can be absolutely depended upon for the making of sorghum or syrups.

Plant from 4 to 8 pounds per acre in rows $3 \frac{1}{2}$ feet apart.

Feterita, a grain which has attracted considerable attention in Kansas, Missouri, and Oklahoma on account of its extreme drought resisting features, its heavy yields, and earliness. It belongs to the Sorghum family. Makes a medium high growth and is about equal to Kaffir corn in feeding value. Often yields from 25 to 35 bushels per acre. If sown in rows and cultivated, 3 to 8 pounds of seed per acre are required, while if sown broadcast for fodder about $1 / 2$ bushel per acre is required.

Kaffir Corn. Another member of the Sorghum family. Making excellent fodder either green or dry. The stalks grow 4 to 5 feet high and are very leafy. They do not harden like other varieties of sorghum, being brittle and juicy and highly relished by all kinds of stock. Will usually yield from 35 to 50 bushels of seed per acre.

Milo Maize. Very similar in growth to Kaffir Corn, but is preferred by many growers who claim that it produces more grain per acre and better quality of forage than any of the nonsaccharine sorghums. It is grown and handled in same manner as Amber Cane or Kaffir for hay and fodder and will make splendid ensilage if cut up with corn. 


\section{Sudan Grass}

Sudan Grass is comparatively a new crop for the United States. It was secured from Khartum, Sudan, Egypt, in 1909. Sudan Grass is an annual of quick growth -the first crop being ready to cut in from fifty to sixty days after seeding, depending on the length of season and amount of moisture. After cutting for hay, it renews its growth promptly when moisture conditions are favorable, and in about 40 to 50 days another cutting is ready. The grass stools abundantly after the first cutting and the second and third cuttings are very fine stemmed. It dies with the first killing frost and your fields are left the same as other stubble land.

The United States Department of Agriculture circular 50 says: "Sudan Grass makes a very nutritious and palatable hay, which is greatly relished by both cattle and horses and has no worse fault than its slight laxativeness. Yields of 2 to 4 tons per acre of cured hay are common, and under irrigation they run as high as 8 to 10 tons. Sudan Grass can be cut green and used as soiling crop to good advantage. No data on its value for pasture have yet been secured, but, being an annual, it would have to be resown each season. The same care should be used in pasturing the second growth as is customary with the sorghums. In feeding value it is no doubt practically identical with the sweet sorghums, as the analyses show it to possess about the same percentage of different food principles.

"Sudan Grass is not particular about the soil, but does best in a fairly rich clay loam. It is fully as drouth resistant as the ordinary cultivated sorghum, and when grown in rows and given similar cultivation it can be relied upon to produce a crop of hay with very little rainfall. This quality allows of its use as a catch crop throughout the corn belt and extends its territorial limit north in the Great Plains region to the north line of South Dakota.

"Sudan Grass should not be planted until the soil has become warm in the spring. It can be sown any time during the summer as a catch crop, so long as 70 to 80 days intervene before the date of the first expected frost. Sown in rows 36 to 42 inches apart 2 to 3 pounds of good seed to an acre are sufficient. Drilled or broadcast 16 to 24 pounds per acre are required."

As a hay crop it gives promise of being of great value in the Great Plains region, the quality of the hay being second only to alfalfa. Seed production has been a source of great profit, yielding from 500 to $2,000 \mathrm{lbs}$. of seed per acre.

Our stock of Sudan Grass seed is of exceptionally fine quality and pure. We want you to try this grass this year and are ready to give you any additional information you desire about this crop.

Japanese Millet. More commonly known as "Billion Dollar Grass." Entirely distinct from other millets. A wonderful forage producing plant, growing from 3 to 6 feet high with a very leafy stalk. It makes excellent hay, in quality is fully equal to corn fodder. Can be fed to all kinds of livestock. The seed head is solid and produces often times from 40 to 60 bushels per acre. However this millet is generally grown for hay. Sow broadcast 15 to 18 pounds per acre or drill in rows 12 to 20 inches apart using 10 to 12 pounds an acre. 


\section{Millets}

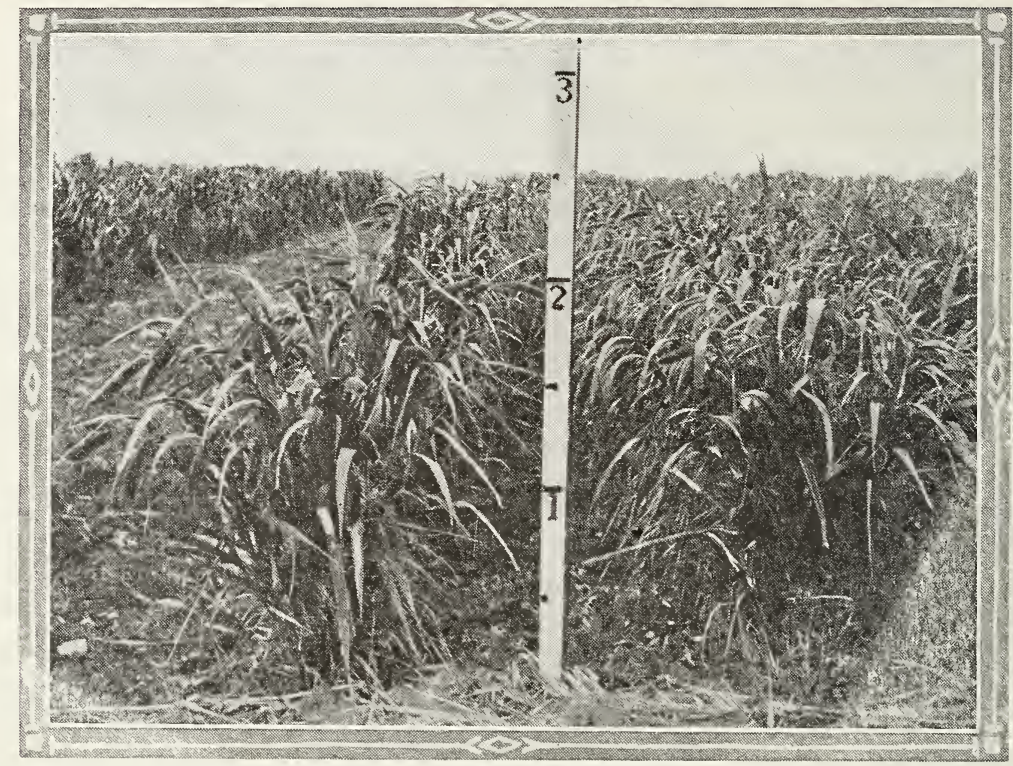

Golden Millet (formerly known as German Millet), is the most popular millet on the market. In the North millet is grown almost altogether for hay, and for that reason the southern grown Golden Millet is the best. It makes a taller more leafy growth which means more hay. It makes a very palatable hay and when fed to dairy cows it produces a large flow of milk. If cut when in full bloom it makes a very tender, sweet, and excellent quality of hay. A bushel of this seed weighs 50 pounds and a bushel will sow two to three acres.

Dakota Kursk Millet. This variety of millet has been on the market now twenty years. It was imported into this country from Kursk, Russia, and has proven itself to be a wonderful producer of a fine quality of hay and seed as well as a very drought resistant plant. This variety is especially. recommended for the dry sections of the country. Our stock is from the Special Select Dakota Kursk seed.

Siberian Millet. This is the same type of millet as the Kursk, producing a large, leafy growth, making an abundance of hay. We have some extra choice Western grown seed.

White Proso Millet. Proso is a grain millet and is found in many colors and varieties in the dry regions of Asia. The grain ripens in 60 days. It may be cut for hay also, but the grain crop is the main item. In its original home Proso is used for human consumption, as breakfast foods and flour. Experiments conducted at the South Dakota Experiment Station at Brookings, So. Dakota, have proven that it is a good substitute for wheat. It is also a very desirable millet for poultry feed or may be ground with other grains and fed with wonderful results to hogs.

Early Fortune Millet. Similar in every respect to the White Proso excepting it is red in color. Like Proso it is a good seed yielder, often producing from 40 to 50 bushels per acre. It is worth your while to try out either or both of these millets.

Common or Northern Millet.

After the Golden Millet has been grown in the North for two or three years it becomes what is known commercially as Common Millet. It still retains many of the traits of the Golden Millet but it loses a part of its rank, leafy growth. It does not yield as much hay nor is the hay of as good a quality as that coming from southern seed. The common millet usually grows from two to three feet high while the Golden will grow from 3 to 5 feet high. We have a very choice stock of common millet seed on hand. 


\section{Field Peas-Soy Beans}

Field peas are one of the best one year crop nitrogen producing plants that can be grown. For this reason they are a great soil enricher and add wonderful producing properties to the soil. This is a fact that should not be overlooked.

Field peas have many uses. The vines make a rich, nutritious hay, which can be fed to milch cows and sheep with very pleasing results. They will increase the flow, of the milk in the dairy herd. When threshed the peas may be ground and fed to stock.

\section{Sowing Canada Field Peas.}

This is the standard variety of field peas. The vines attain a height of from 3 to 4 feet, and if allowed to mature, the yield often varies from 30 to 40 bushels per acre.

When sown alone about 3 bushels of seed are required per acre. They can be matured and threshed when dry.

Peas and oats are often sown together

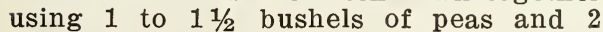
bushels of oats per acre. If cut green for hay this combination gives a surprising amount of feed per acre. They may also be allowed to mature and can be harvested and threshed.

Peas sown in the corn field at the time the corn is laid by provides a combination of feeds that is unexcelled for hogging down or for sheep pasture.

\section{Soy Beans.}

Ito San Soy Beans. Much interest has been shown, during the past year or two, by all leading agriculturists in Soy Beans.

The Ito San variety is a decided favorite in many sections, particularly in the Northern states and its popularity is growing rapidly.

For hogging down with early varieties of corn (one-third beans and two-thirds corn) it cannot be excelled. Hogs will gain $20 \%$ more on Soy Beans fed with corn than they will on corn alone. Soy beans are also used as a soiling and hay crop by many leading dairymen, who say they "cannot get along without it."

Early Black Soy Beans are grown in Minnesota and Wisconsin, where they have proven a profitable type. An extremely early variety like this is equally desirable for every other sections.

Soy Beans should be planted after corn planting in rows two to three feet apart using from one-fourth to one-half bushel per acre. If sown broadcast from 40 to 50 pounds of beans per acre.

Navy Beans. Our stock is extra select, hand picked, true type, small sized navy beans. Good yielders, and being Dakota grown, are acclimated to northern territory. This variety is giving the best of satisfaction. Sow 30 to 35 pounds per acre in drills 30 inches apart.

\section{Buckwheat}

Japanese Buckwheat. The seed is a rich dark brown in color and much larger than the Silver Hull. Buckwheat remains in bloom for some time after the first seed is ripe. It is especially desirable for bee pasture. When plowed under makes excellent green manure. Sow as late as possible and still have crop well developed before severe frost occurs. Light, well drained soils are best for this crop. Sow about 50 lbs. seed per acre.

Silver Hull Buckwheat, is earlier, remains in bloom longer than other varieties. A fine variety for honey bees. The grain is light gray in color and has a thin hull. Silver Hull is much preferred by the millers as it makes a richer, whiter flour. Under favorable conditions will yield from 40 to 50 bushels per acre. 


\section{Disco Clovers}

As with the DISCO brand alfalfa, seed corn and other DISCO seeds, the same high standard of purity and germination is maintained with our clovers and timothy. This means a great deal more to you than is signified by these words. Why take the chances of sowing seed of unknown or doubtful purity and germination when you can buy the dependable DISCO brand seeds?

All the DISCO clover and timothy seed must pass the pure seed laws of every state. All lots of seed are tested in the U. S. Seed Testing Laboratory. The results of these tests are given to you on the shipping tags put on your shipment. Does such information mean anything to you? To confirm these tests on the DISCO guaranteed seeds, we are always glad to have you send samples of the seed to your State Agricultural College to be tested out. If figures compare favorably our guarantee is fulfilled.

Medium Red Clover. Red clover is the staple leguminous forage crop in the North Central and Northeastern States. While the Red Clover Seed Crop has not been a large crop the past season, our immediate territory has been favored with a good crop for extra fancy seed. We have a large stock of DISCO Quality Red Clover on hand and are prepared to fill your orders at a very fair price, quality considered.

It is very important that considerable care be taken in choosing the seed to be sown. If poor seed be used a crop failure may be expected. Good Red Clover seed is plump or well filled, bright with a slight luster, the color of individual seeds range from violet to light yellow. The seed should be free from adulterants of any kind and also free from seeds of noxious weeds.

You will find DISCO Medium Red Clover of the highest quality obtainable. Complying in every respect with the DISCO Guaranteed Seed standard.

Medium red clover is regarded as the most valuable of the Clover family. It is a dependable, all around variety for farmers and stock men. Clover is a nitrogen gathering plant which enriches or inereases the fertility of the land on which it is grown. Clover should be rotated with grain crops every 3 to 5 years.

Clover may be seeded either in the spring or fall, with or without a nurse crop. Sow 8 to $10 \mathrm{lbs}$. of seed per acre.
Mammoth Red Clover is a much coarser variety than medium red. It does well for hay if cut early but is prin: cipally used as a pasture clover and a fertilizer. It is especially desirable to sow two or three pounds of Mammoth Red Clover seed per acre with the small grain in the spring. Its rapid growth after harvest insures a good pasture and when the crop is plowed under it makes the best of green manure.

Alsike or Swedish Clover produces the finest quality of clover hay. It is the hardiest of all clovers, and is well adapted as a pasture clover. Alsike thrives best on low or moist lands. It is an ideal clover to mix with timothy, as it cures as readily as the timothy. Its yields of hay are well in its favor. Sow 6 to 8 pounds per acre.

White or Dutch Clover. Is a low, close growing clover usually not attaining a height of more than 4 to 6 inches. The leaves are small and the flower round, white with a pinkish tint in color, and very fragrant. This variety is especially adapted to lawn and pasture purposes as it will stand very close cropping without injury. Does well on most any soil. It is usually best to sow with other grasses, using from 2 to $6 \mathrm{lbs}$. of seed per acre.

Red Top Solid Seed, commonly known as Herd's Grass, has thick roots and makes a very firm sod which makes it very desirable for pasture purposes. Red Top will grow where the soil is too poor for timothy and other grasses. Especially desirable to sow on rather moist soil. It is a good grass to sow with timothy and clover for both meadow and pasture and is more hardy than either of the two. Red Top grows from 1 to 2 feet high, with a good thick undergrowth. Yields from 1 to 2 tons of excellent hay per acre. For the best quality of hay it should be cut when in full flower. Sow from 10 to 12 pounds of solid seed per acre. 


\section{Disco Timothy}

Timothy. The best and most widely known of all grasses, and the leading grass in many sections for meadow and pasture. It is extremely hardy; very seldom winter kills and stands heat and drought equally as well. Timothy is adapted to many soils but seems to do best on a clay loam. Will stand considerable moisture without damage. There are several items in its favor. It is easy to establish, making a very quick, rapid growth. The seed is inexpensive as compared with many other grasses. It yields from one to two tons of hay per acre. The hay grows about waist high with a slender stem and reasonable amount of leaves, which cure readily, when cut.

Many experiments have shown that timothy rapidly exhausts the nitrogen in the soil. This condition may be improved upon by occasionally manuring the field or by the use of other fertilizers. The most natural way to keep up the fertility of the soil is to sow timothy and clover mixed. This makes an excellent combination, and produces better quality of hay. To get the highest feeding value out of timothy, the hay should be cut when in full bloom or soon after.

The DISCO timothy seed is all Dakota grown. It has been thoroughly recleaned, is of excellent color and high purity and germination. Sow 10 to 12 pounds of seed per acre.

We are offering a special on DISCO timothy this season. Be sure and take advantage of it. Look up the price.

Timothy and Alsike Mixed make one of the most desirable combinations of seed for meadow purpose. They are both very hardy plants and the hay from this combination is richer in feeding values than timothy alone.

The seed we are offering is about onethird alsike and two-thirds timothy. This makes a good rich combination. Sow 12 to 15 pounds of this mixture per acre.

Timothy and Medium Red Clover mixture of the same proportion may be had at a little higher figure.

Permanent Pasture and Meadow Mixtures. In these mixtures we are able to supply you with grasses and clovers which are especially adapted to a large variety of soils. In placing your order if you will state whether you want it for either "high dry land" or "low wet or moist land" we will supply you with seed that will meet your requirements. These mixtures contain Red Top, Kentucky Blue Grass, Meadow Fescue, Perennial Rye Grass, Timothy, Alsike, Medium Red Clover, Alfalfa and White Clover. Sow from 20 to 30 pounds per acre.

\section{Dakota Improved Seed Co.'s "Disco" Lawn Grass Seed}

No one in the world is in better position to have and maintain a smooth, velvety lawn around the house, than the American farmer. A beautiful lawn not only adds value to a home but it adds enjoyment and satisfaction.

On the farm you have the advantage of selecting the ideal building spot. The soil is good, and the required fertilizer is available. The main point left is the selection of the proper seed.

In mixing DISCO Lawn Grass we have combined the very best and most choice grasses that make a quick growth and a velvety turf. Great care is exercised in using the very best of recleaned seedpure, clean and free from foul seeds.

A mistake which is commonly made in starting a lawn is that of using too little seed. A thick stand is essential at the beginning and in order to be certain a seeding of from 4 to 5 pounds to 1,000 square feet is necessary.

The United States Department of Agriculture, Washington, D. C., has published Department Circular 49 on "Making and Maintaining a Lawn." This is very interesting and essential for those interested in making and maintaining a lawn. Send for a copy. 


\section{Disco Grasses}

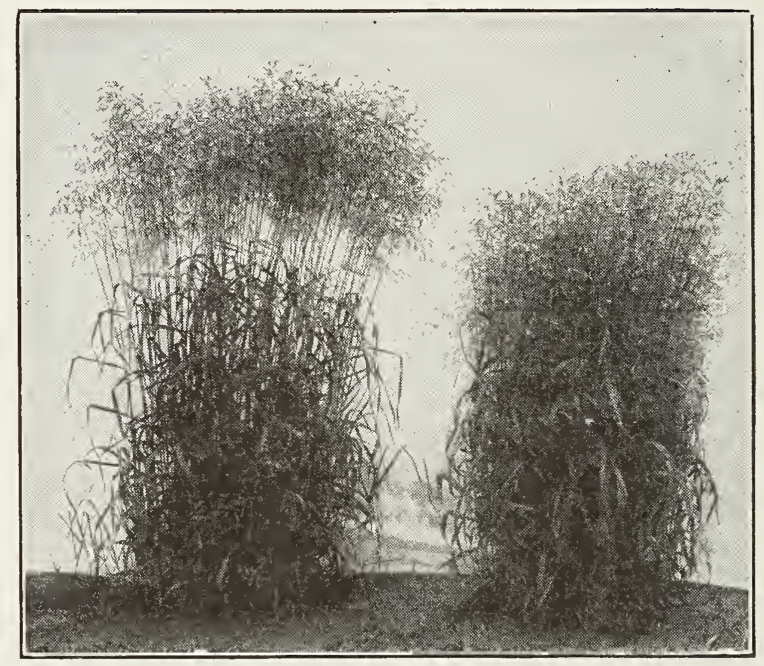

Russian Brome Grass (Bromus Inermus) showing two types of plants.

Bromus Inermus. A native of Russia. A grass that is well adapted to a cold climate. One of the deepest rooting grasses on the market. Suited to a dry soil. Makes the best of pasture getting green the first thing in the spring and late in the fall.

Brome Grass thickens up rapidly, making a dense growth of leaves which start close to the ground. Produces an abundance of hay which is relished by all kinds of livestock.

It is extremely hardy and is very seldom winter killed. It can stand an abundance of water. Well adapted to a large variety of soils. Especially recommended for the Dakotas and Minnesota. Sow from 20 to 25 pounds per acre.

Kentucky Blue Grass is sometimes called "June Grass." It makes a very good pasture grass for all kinds of live stock. The sod is thick. The plant is very hardy and stands the cold and dry weather remarkably well. Blue Grass is one of the first grasses to be green in the spring. It is not advisable to pasture Blue Grass until the sod is well established.
Blue Grass is also a very popular grass for lawn purpose, mixing white Dutch clover makes a beautiful velvety lawn.

For pasture sow from 30 to 40 pounds per acre while for lawn 70 to 80 pounds of seed per acre should be used.

Meadow Fescue or English Blue Grass does well on poor soil and makes a wonderful growth on good land. The roots penetrate deep and the plant stands drought to a marked degree. Especially desirable for pasture and is also fine for hay. It grows from two or three feet high. The hay is very nutritious and cattle thrive well on it. Sow from 25 to 30 pounds of seed per acre.

Perennial Rye Grass. Becoming one of the well known pasture grasses. Stands close cropping. Does well on land suitable for corn production. Producing an abundance of forage. The hay is relished by all kinds of stock. Sow 15 pounds per acre.

Crested Dogstail. A hardy grass making a smooth, compact and lasting turf. Roots deeply and withstands dry weather. Does best on rich, moist land but will grow on most any soil. Sow 30 pounds seed per acre. 


\section{Disco Select Northern Grown}

\section{Small Grains}

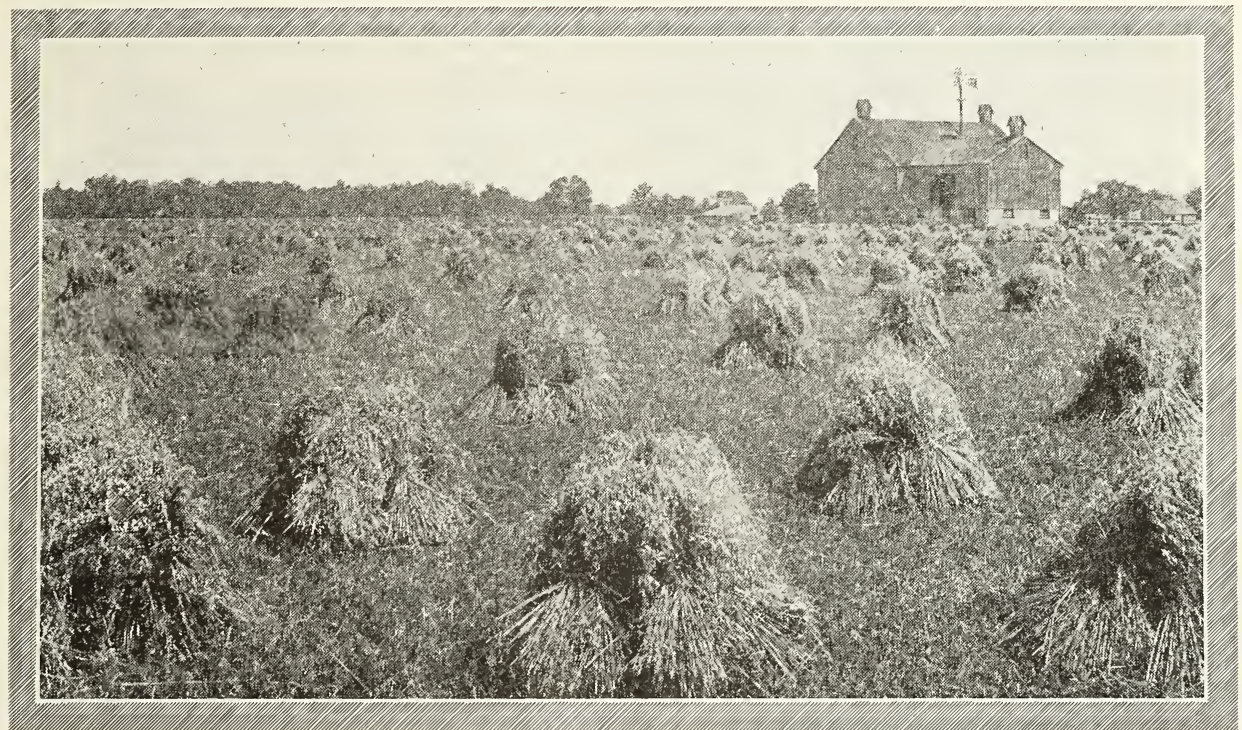

There are many varieties of oats offered on the market. Tests of many of these varieties have been made on the Riverview Ranch. From these there are the three following varieties which have proven themselves to be worth while for this northern latitude.

Swedish Select. This variety has become well known throughout the country, and especially in South Dakota, Minnesota and Wisconsin; also Montana. The experiment stations of Wisconsin and South Dakota have been foremost in introducing this variety. Today it is standard and found to be wonderfully drought resistant. In the region between the James and Missouri rivers, a dry period often comes in the early part of the growing season. At this time many varieties of oats are seriously injured by drought. The Swedish Select, however, has shown itself capable of resisting dry weather at this season of the year and in fact has produced some of its largest yields in such seasons.

Its habits of growth are so vigorous that on heavy soils it is likely to lodge, but on light soils it has no superior. Sow 2 to $2 \frac{1}{2}$ bushels per acre.

Swedish Postia oats. Evéry year the Swedish government is experimenting with various varieties of small grain. At last they have found something. the Postia Oats, that outrival the Swedish Select. The Pos: tia has only been grown in this country four years. Its first American home was in Wisconsin. Then the seed was brought to Mitchell, where it has been grown for the past two seasons with marked success.
This variety was bred up from the large white oats. The grain is good sized, white in color, plump and heavy, very strong straw, and a heavy producer. Particularly adapted to thin, light soils.

Our seed is exceptionally fine quality, having been thoroughly recleaned. You cannot buy better stock at any price. Get started on these new oats this year. Sample on request. See special price list.

Sixty-Day. A very early yellow variety much resembling the Kherson in every particular, but much hardier and ripens about same time as barley. Was imported from Siberia several years ago, making a splendid addition to the small grain varieties. We can recommend the Sixty-Day as being a good yielder, stand up with stiff straw and not subject to rust.

Barley is the most certain crop regardless of the season. Is very drought resistant, yielding splendid returns in dry farming areas. Seldcm lodges even in rich moist places owing to a stiff straw, which is also rust resistant. Yields vary but are usually well worth while. In comparative feed values, tests have been made which show that 500 pounds of ground or soaked barley is equal to 400 pounds of shelled corn.

Manshury Barley. The best variety and probably better known than any other variety offered to the farmers of the United States. It produces a good plump grain high in protein. The straw is strong and stiff, and seldom lodges. The heads are long and well filled, and carry 6 rows of good plump grain. You will do well to sow a few acres of Manshury. 


\section{Spring Wheat}

\section{Sow about $1 \frac{1}{4}$ bushels per acre.}

Marquis Wheat. A heavy yielding beardless variety absolutely without a peer. It originated in Canada by crossing Red Fife with Hard Calcutta wheat. The Calcutta was a native of India which became acclimated to northern conditions. Marquis is an early spring wheat, very hardy, withstands very dry weather at growing season as well as severe weather at planting time.

Marquis wheat is from one week to ten days earlier than any other variety of spring wheat. It will outyield other varieties of spring wheat from 5 to 10 bushels per acre under same conditions. The straw is medium height, stiff and strong. Matures early enough so the rust, smut, drought and hot winds do not have so much of an effect on it. The kernel is short, thick, plump and flinty, and rather a dark amber color. One of its main fea- tures is that it is beardless, and does not shatter easily. In changing your seed this season, consider the Marquis with increased yield and earliness in its favor.

Kubanka Wheat. It is bearded wheat of a Durum or Macaroni variety. It has been grown on the DISCO farm for the past three years with wonderful success. Have found it to be a great drouth and rust resistant. All the agricultural experimental stations' reports place this variety at the head, or nearly so, of the list, both in yield and hardiness. Yielding better than other varieties of Durum.

Try a few acres of this Kubanka wheat and increase your profits.

Turkey Rerl Winter Wheat. A standard red bearded winter wheat with a stiff straw. Ripens early, and a big yielder. The kernels are red, hard and flinty. The best winter wheat on the market.

\section{Speltz or Emmer}

The value of this wonderful grain crop is not fully appreciated. It has been grown in the United States for a number of seasons, and is rapidly increasing. It is found to be adapted to a large variety of soils and climate. Especially desirable for the Northwest Great Plains region. It is very drought resistant and a good yielder, often yielding from 35 to 50 bushels per acre.

During the past season trials and tests have been made to work this grain into a flour substitute. The results have been very pleasing. It mixes well and makes a good dough without the adding of wheat flour. Makes good white bread and excellent pastry flour. Speltz will find more of a ready market for this purpose in the future.

It is readily eaten by all kinds of live stock, and shows itself especially adapted for the feeding of milch cows and hogs. It makes a very heavy feed when fed alone and on that account it is advisable to mix bran or shorts with it.

Give Speltz a place on your farm. Two bushels ( 84 lbs.) required to sow an acre. 


\section{Rye}

Sow $1 \frac{1}{4}$ bushels seed per acre.

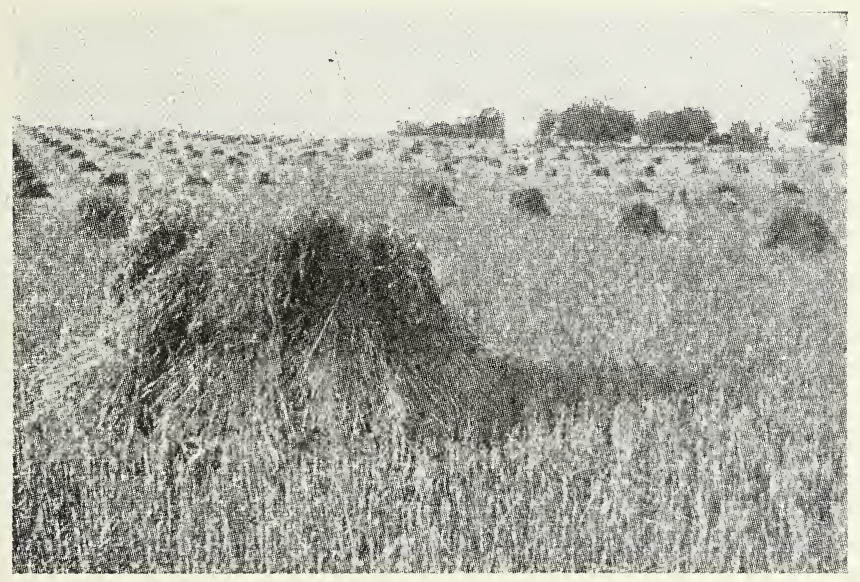

Winter Rye.

SPRING RYE. Genuine Pure Spring Rye, Sown in the Spring and Harvested the same Season. Spring Rye makes an excellent crop. It does not grow quite so large a straw as the Winter Rye. The quality of the grain is excellent and the yield is usually from 25 to 35 bushels per acre. Spring Rye is sown in the spring the same time as other Spring grain crops. We have a large true stock of Spring Rye of excellent quality. Take advantage of this opportunity to get the genuine Spring Rye.

Amber Winter Rye, is a much hardier winter grain than Winter wheat and can be grown on a larger variety of soils. Very drought resistant and does well on light sandy soil. Rye is put to many uses, as for grain, fodder, soiling purposes and green manure. Makes excellent pasture for pigs, calves, and other stock. Rape may be sown with it in the spring to increase the length and value of the spring pasture.
Amber Winter Rye should be seeded between Aug. 15th and Sept. 15th. If drilled about $2 \frac{1}{2}$ inches deep there will be less danger of winter killing.

DISCO Improved White Hulless Barley.

Crop Failure.

Seed Flax. Flax is especially adapted to the soil and climatic conditions of our northern states. There is an increased demand for flax seed and with the normal yield of from 12 to 15 bushels per acre it is a very valuable crop to grow. Flax should not be sown on the same land oftener than about once in seven years. The seed should be treated before seeding, using one pint or pound of formaldehyde to 40 gallons of water.

Our seed all comes from new land, and is of very fine quality. Sow during the first half of June, using $1 / 2$ bushel per acre.

For Prices See Special Sheet Inside of Front Cover. 


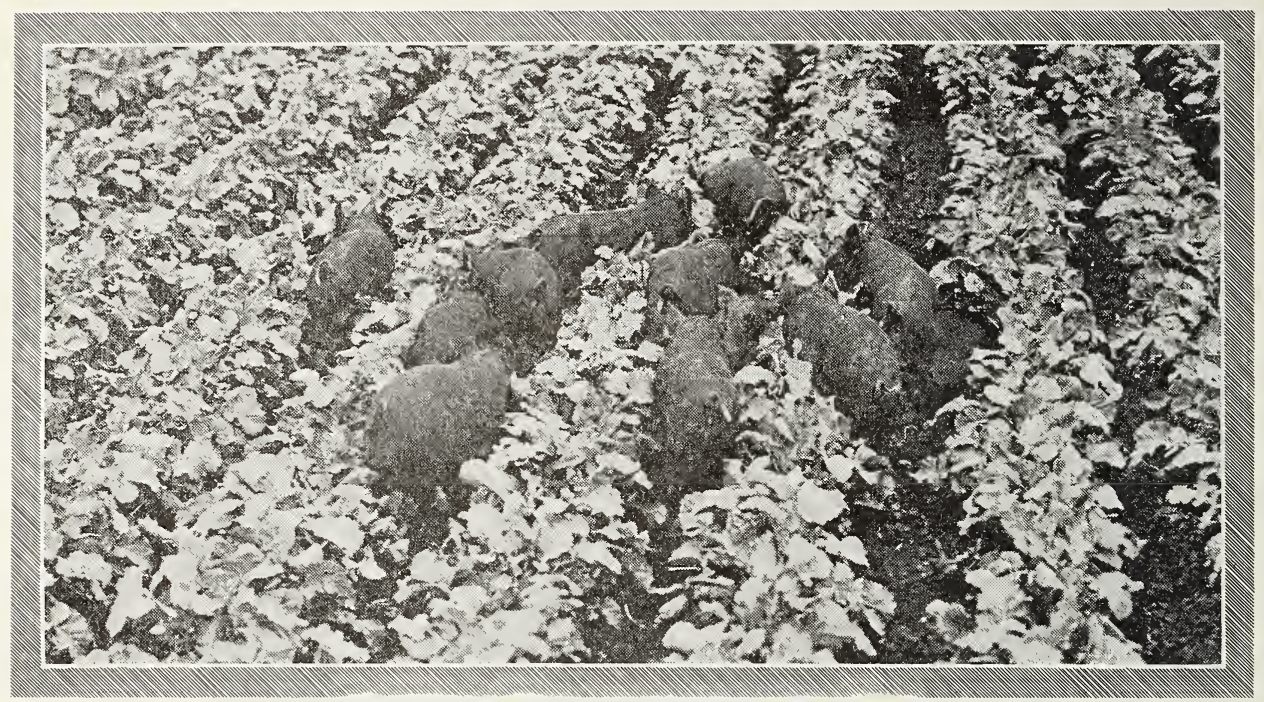

A most excellent pasture for young pigs.

Rape can be put to a number of uses. It may be sown alone as a spring crop to provide early pasture. It may be sown with spring grain to provide fall pasture after the grain is cut. In this latter case it is better sown after the grain is up and the ground dragged immediately after sowing to cover the seed. As it is a common practice to drag or weed our grain crops after they are up, the sowing of rape at this time can be easily done. Rape may also be sown just before the last cultivation of corn to provide fall feed and increase the yield of feed per acre, or rape may be sown with fall rye to provide fall pasture.

The uses of rape are hardly limited to those mentioned above, as it may be sown at almost any time during the spring, summer or early fall and will provide quickly a large amount of forage.

The farmers of the Northwest have not yet come to realize the possibilities of rape. There are thousands of acres of land sown to small grains that could be made to yield an abundant fall pasture by the sowing of two pounds of rape seed to every acre of ground. The cost of the seed is so little and so small an amount is required that there is really no expense connected with it compared to the value of feed that is secured. The amount of seed that is sown per acre varies from two to six pounds, depending upon the way it is handled. When sown alone, from five to six pounds are recommended. When sown with small grain, two to three pounds.

\section{ANNUAL HOG PASTURE MIXTURE.}

Last spring some of our local trade demanded something just a little different for a hog pasture. After carefully considering what would be best adapted to this purpose we prepared an Annual Hog pasture mixture that makes an immense quantity of feed. It has proven of such economic value not only to swine but all other livestock that our customers are demanding this in larger quantities again this year.

Make all the waste patches about the pasture lot produce the feed they should by sowing the Annual Hog pasture mixture. It is sown about cornplanting time using from 35 to 50 lbs. per acre.

The results will please you because this mixture furnishes the variety they need. 


\section{Please Read Before Ordering}

When orders are received from this Catalog the Dakota Improved Seed Company assumes that the customer has read this page before placing his order.

Write plainly your name, postoffie, county and state on each and every order sent us. If shipment is to be by freight, be sure to state whether the railway station is the same as your postoffice or not.

Order early. A great many delays and other troubles can be avoided by ordering early and we will consider it an accommodation if you will do this.

Cash should accompany order, and should be in the form of money order, bank draft or as currency in a registered letter.

Delays in shipment. If we cannot send your order the same day that it is received we will mail you a card stating that we have received your order and we state the amount of money inclosed and the number of the order. If this notice or the seeds themselves do not reach you in reasonable season write us without delay, so that we can look the matter up. If your order can be filled within a few days this is all the notice we give. If for some reason shipment on a part or all of your order is unavoidably delayed, we will give you notice. It some times happens that we are out of stock or our stock may not be cleaned ready for shipment, or there may be other reasons. Write to us if your order does not arrive in due season.

Prices in this book are subject to change without notice. The prices quoted are based on the conditions prevailing at the time this book goes to press. If you desire to place an order for items on which the prices are likely to fluctuate or for large amounts of any seeds, it is better to write for firm prices before ordering, same to be good for immediate acceptance. Prompt attention will be given requests for quotations.
I like your method of doing business and I believe that it will prove a winner with the farmers throughout the country.

C. H. Lugg, Parkston, S. D.
Your seeds are first class. I have found your way of doing business fair, straight and honest.

I. G. Fjerstad, Bryant, S. D

We will consider it a Special Favor if you write below the Names of some of your Friends who are likely to use Field Seeds

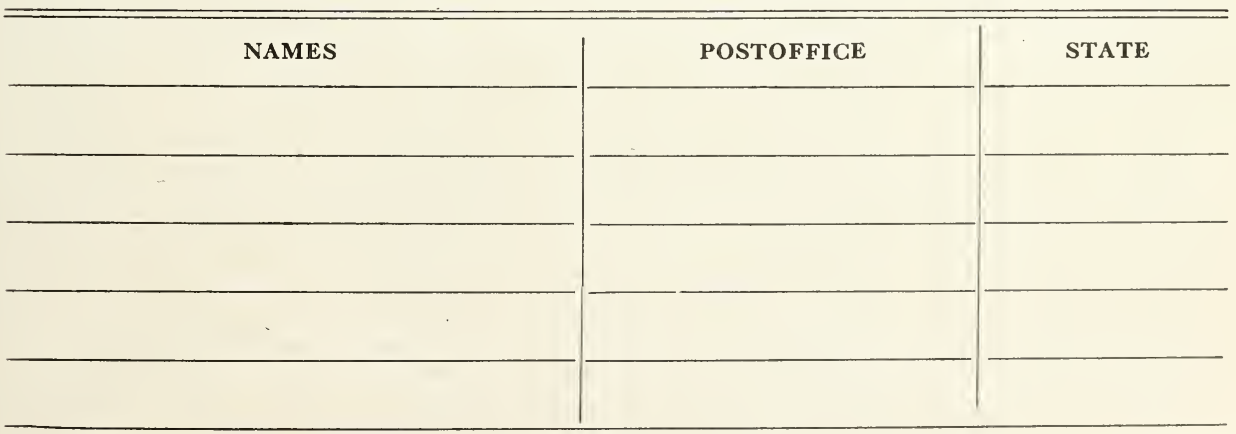




\section{Oisces Order Sheet}

Date................

Dakota Improved Seed Co., Mitchell, South Dakota.

Gentleman: Please send the following seeds.

by

State here if wanted by freight, express or parcel-post.

Name

Post Office

County

State

R. D., P. O. Box or St. No.

Nearest Railway Station

State here name of town to which goods are to be sent if different from P. O.

Is there a freight agent at your railroad station?......

If there is no freight agent at your shipping point, money must be sent with order to prepay the freight charges.

This order is placed subject to the guarantee and conditions of sale given in the DISCO Seed Book.

\section{'State Amount Enclosed}

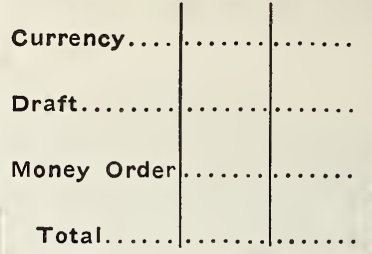

Please Do Not Use This Space Order Received

Order No.

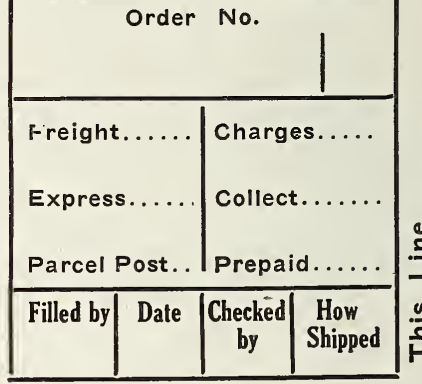

\begin{tabular}{|c|c|c|}
\hline QUANTITY & SEEDS OR OTHER ARTICLES WANTED & Amount \\
\hline & & \\
\hline & & \\
\hline & & \\
\hline & & \\
\hline & & \\
\hline & & \\
\hline & & \\
\hline & & \\
\hline & & \\
\hline & & \\
\hline & & \\
\hline & & \\
\hline
\end{tabular}




\section{GUARANTEE}

The Dakota Improved Seed Company Guarantees the Seeds It Sells to Be as Repre. sented as to Quality and Germination. The Company Will Replace Any Seeds or Refund the Money on Any Seeds Sold by It That

\section{Prove to Be Otherwise}

It shall be the duty of the purchaser of goods sold by the Company in order to claim the benefits of its guarantee:

1. To inspect shipment carefully on arrival and report anything that appears wrong.

2. To take samples of all important bulk seeds in shipment.

3. Upon receipt of seed to test portion of sample for germination or send sample to U. S. Seed Laboratory, or to your State Experiment Station.

4. If results of these tests are not as represented or are not satisfactory, to report this to the Company at once and adjustment will be made accordingly.

5. To make complaints, if any, as soon as the fact on which complaint is made can be determined. Complaint on the germination of seed corn must be made within two weeks after shipment is received. Field results as to germination and purity may be referred to in making complaint, but must not be depended upon as basis for settlement because field conditions are beyond the Company's control.

The Company will not insure a crop from seeds purchased as to description and productiveness because of the many factors which influence a crop and which are entirely beyond its control.

In no case will the liability of the Dakota Improved Seed Co. exceed the price paid for the seed purchased of the Company.

\section{FREIGHT RATES FROM MITCHELL, SO. DAK.}

\section{In Efrect January 1st, 1920.}

These rates are not guaranteed, but are made up from the tariffs now on file, and subject to change without notice.

Rates Given in Cents per 100 Pounds, Less than Car Lots.

Alfalfa, Clovers, Grass Seeds, and Cane Seed take third class; Grain, Corn and Feeds take fourth class as per Western classification.

\begin{tabular}{|c|c|c|c|c|c|c|c|c|c|}
\hline & & $3 d$ & th & & $3 d$ & th & & $3 \mathrm{~d}$ & $4 \mathrm{th}$ \\
\hline $\begin{array}{l}\text { een, s } \\
\text { ar, }\end{array}$ & S. D. & $\begin{array}{l}.35 \\
.231 / 2\end{array}$ & $\begin{array}{l}.261 / 2 \\
.18^{1 / 2}\end{array}$ & $\begin{array}{l}\text { Salem, } \\
\text { Tripp, }\end{array}$ & $\begin{array}{l}.201 / 2 \\
.201 / 2\end{array}$ & & $\begin{array}{l}\text { Butte, Mont. } \\
\text { Billings, }\end{array}$ & $\begin{array}{l}1.971 / 2 \\
2.051 / 2\end{array}$ & \\
\hline & “ & & & yndall, “ & & & Lewiston, " & & $1.571 / 2$ \\
\hline $\begin{array}{l}\text { e l l e } \\
\text { Fourche. }\end{array}$ & & & & $\begin{array}{l}\text { Underwood, " } \\
\text { W o o n- }\end{array}$ & 1.1 & & $\begin{array}{l}\text { Terry, } \\
\text { Charles }\end{array}$ & & \\
\hline uffalo & & 100 & & socket, “ & $.181 / 2$ & .14 & City, Ia. & $.711 / 2$ & .56 \\
\hline $\mathrm{G}$ & “" & $\begin{array}{l}1.20 \\
45\end{array}$ & & Wolsey, “، & & & Cedar Rap- „، & & \\
\hline & “ & .45 & & $\begin{array}{l}\text { tertown. “" } \\
\text { oridge. }\end{array}$ & .43 & $\begin{array}{l}.32 \\
.32\end{array}$ & $\begin{array}{l}\text { ids, } \\
\text { Des Moines, ", }\end{array}$ & $\begin{array}{l}.711 / 2 \\
.66^{1 / 2}\end{array}$ & $\begin{array}{l}.561 / 2 \\
.51\end{array}$ \\
\hline a- & & & & Yankton, " & & & $\mathrm{E}$ a $\mathrm{g} 1 \mathrm{e}$ & & \\
\hline & “ & $\begin{array}{l}.18 \\
.43\end{array}$ & .1 & ley, N. D. & & & Grove, & .6 & .59 \\
\hline er- & & & & n d & & & $\begin{array}{l}\text { Le Mars, } \\
\text { Manilla, }\end{array}$ & & $\begin{array}{l}.2 \\
.4\end{array}$ \\
\hline & “ & .26 & .19 & Forks, & 1.04 & .8 & k Val- & & \\
\hline in, & “ & .26 & & Hettinger, “" & & & $y$ & .34 & $.26^{1 / 2}$ \\
\hline & “ & .30 & & estown," & & & orn, “ & .4 & \\
\hline & “" & $\begin{array}{l}.96 \\
.33\end{array}$ & & 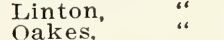 & $.661 / 2$ & & ux City. “ & & \\
\hline $\begin{array}{l}1 \text { lk Point, } \\
1 \text { a n- }\end{array}$ & 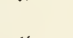 & & & $\begin{array}{l}\text { Oakes, } \\
\text { Minot, }\end{array}$ & 1.22 & & $\begin{array}{ll}\text { Chicago, } & \text { Ill. } \\
\text { St. Louis. } & \text { Mo. }\end{array}$ & & \\
\hline $\mathrm{dr}$ & “" & & & h $\mathrm{p} \mathrm{e}-$ & & & Buffalo, N. Y. & 1.5 & \\
\hline urg. & “" & .48 & & on, & & & Tex. & & \\
\hline ard, & “ “ & $\begin{array}{l}.45 \\
.26\end{array}$ & & ton, Minn. & 1.02 & .8 & Col. & 1.5 & 1.18 \\
\hline bec, & “" & & & $\begin{array}{l}\text { Duluth, } \\
\text { Fergus }\end{array}$ & & .56 & Kan. & .8 & .59 \\
\hline $\begin{array}{l}\text { bec, } \\
\text { on, }\end{array}$ & “ & & & $\begin{array}{l}\text { Fer } \\
\text { F }\end{array}$ & .92 & .78 & Mil & & \\
\hline Bo & “ & & & $\begin{array}{l}\text { St. Cloud, } \\
\text { Marshall, }\end{array}$ & & & La Crosse," & $\begin{array}{l}.8 \\
.5\end{array}$ & \\
\hline do, & “ & & & $\begin{array}{l}\text { Wort } \mathrm{r}- \\
\text { ington. }\end{array}$ & & & San Francis- & & \\
\hline & “ & & & $\begin{array}{l}\text { ington. } \\
\text { Winona, }\end{array}$ & & & $\mathrm{co}, \quad \mathrm{Ca}$ & & 2. \\
\hline t. & “6 & & & neapo- & & & $\begin{array}{l}\text { Seattle, } \\
\text { Ogden }\end{array}$ & & \\
\hline king- & "6 & & & lis, & .5 & & New $\bar{Y}$ or $k$ & & \\
\hline e. & “ & & & $\mathrm{L}$ & & & City & & \\
\hline & “" & & & Om & & & nore. M & & \\
\hline & “ & & & M i 1 e s & & & n, Мas & & \\
\hline & “ & & & City, Mont. & 1.3 & .9 & and, $?$ & & \\
\hline & , & & & shell, & 1.60 & $1.311 / 2$ & Pittsburg. Pa. & 1.58 & $1.16^{1}$ \\
\hline
\end{tabular}




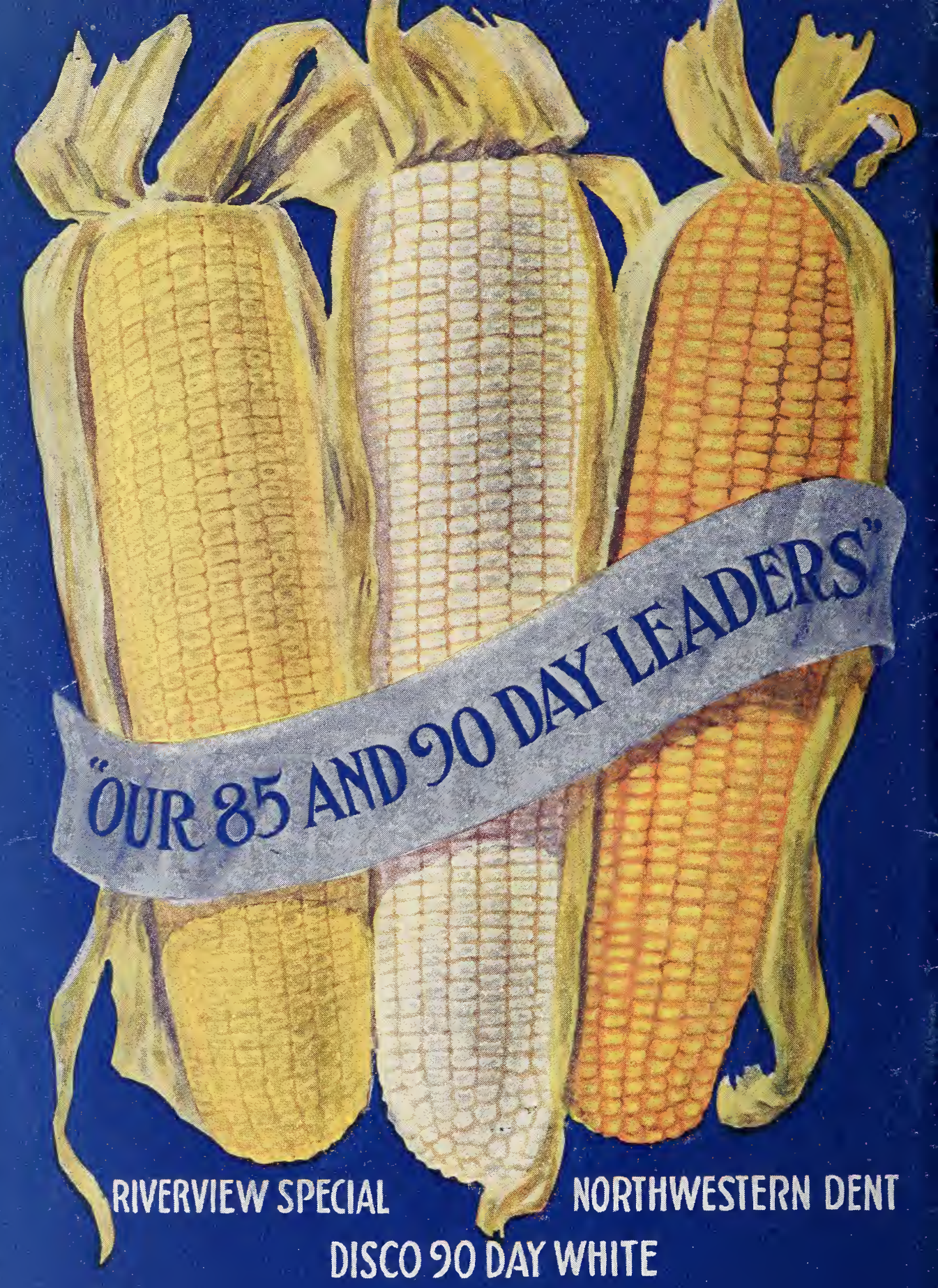

